NBER WORKING PAPER SERIES

\title{
LOANS ON SALE: CREDIT MARKET SEASONALITY, BORROWER NEED, AND LENDER RENTS
}

\author{
Justin Murfin \\ Mitchell Petersen
}

Working Paper 20310

http://www.nber.org/papers/w20310

\author{
NATIONAL BUREAU OF ECONOMIC RESEARCH \\ 1050 Massachusetts Avenue \\ Cambridge, MA 02138 \\ July 2014
}

Petersen thanks the Heizer Center at Northwestern University's Kellogg School for support. The views expressed in this paper are those of the authors. We appreciate the suggestions and advice Lamont Black, Sudheer Chava, Francisco Covas, Jim Dana, Jesse Davis, Victoria Ivashina, Steve Karolyi, Jose Liberti, David McLean, Chris Parsons, and Michael Vondriska as well as seminar and conference participants at the Board of Governors of the Federal Reserve System, Catholic University of Portugal, Chicago Federal Reserve Bank Structure conference, Depaul University, Drexel University, the European Finance Association meetings, the Financial Intermediation Research Society conference, Goethe University, Federal Reserve Bank of San Francisco, Federal Reserve Bank of New York, Harvard Business School, Northwestern University, Texas A\&M University, the Universities of Chicago, Mannheim, Maryland, Michigan, Porto, Oregon, Oxford, Southern California, the University of Utah Winter Finance conference, Villanova University, Washington University, the Western Finance Association Meeting, and Yale University. The research assistance of David Kim and Thomas Kim is greatly appreciated. The views expressed herein are those of the authors and do not necessarily reflect the views of the National Bureau of Economic Research.

NBER working papers are circulated for discussion and comment purposes. They have not been peerreviewed or been subject to the review by the NBER Board of Directors that accompanies official NBER publications.

(C) 2014 by Justin Murfin and Mitchell Petersen. All rights reserved. Short sections of text, not to exceed two paragraphs, may be quoted without explicit permission provided that full credit, including $(\subset$ notice, is given to the source. 
Loans on sale: Credit market seasonality, borrower need, and lender rents

Justin Murfin and Mitchell Petersen

NBER Working Paper No. 20310

July 2014, Revised December 2015

JEL No. G21,G32,L1

\begin{abstract}
$\underline{\text { ABSTRACT }}$
The market for corporate credit is characterized by significant seasonal variation, both in interest rates and the volume of new lending. Firms borrowing from banks during seasonal "sales" in late spring and fall issue at 19 basis points cheaper than winter and summer borrowers. Issuers during cheap seasons appear to have less immediate or uncertain needs, but are enticed by low rates to engage in precautionary borrowing. High interest rate periods capture borrowers with unanticipated, non-deferrable investment needs. Consistent with models of intertemporal price discrimination, seasonality is strongly associated with market concentration among a few large banks with repeated interactions.
\end{abstract}

Justin Murfin

Yale University

165 Whitney Avenue

New Haven, CT

justin.murfin@yale.edu

Mitchell Petersen

Kellogg School of Management

Northwestern University

2001 Sheridan Road

Evanston, IL 60208

and NBER

mpetersen@northwestern.edu 


\section{Introduction}

Predictable and pronounced seasonal variation is not uncommon in commodity prices. Systematic patterns in the demand or supply of a product can lead to corresponding patterns in prices over the calendar year. Yet these seasonal patterns can only persist in the presence of frictions preventing intertemporal substitution by buyers or sellers. For example, electricity prices are high during peak summer demand, but inefficiencies in electricity storage prevent customers from smoothing demand by buying during cheap seasons for later use. ${ }^{1}$ Wheat prices tend to fall during harvest because "many farmers dispose of their crop as it is harvested to avoid...costs of handling and storage” (Meinken (1955)), but as storage costs have fallen, the seasonality of agricultural commodities has diminished.

The presence of pronounced seasonal variation in the cost of financial capital, however, is unexpected in a modern and diverse economy with well-developed capital markets. In theory, storing capital should be very low cost and, while individual industries may have specific seasonal funding demands, one might expect the aggregate seasonal component across a diverse set of industries to be low. In this paper, we show that the market for syndicated loans is characterized by significant and predictable seasonal variation, both in interest rates and the volume of new loans. Firms borrowing during seasonal “sales” in late spring and fall (May/June and October) issue at 19 basis points cheaper and raise 50\% more total funding than winter and summer borrowers (January/February and August). This seasonal pricing is clearly visible in Figure 1: the solid line plots the average monthly loan spread for new issue loans reported by DealScan from 1999 through 2007. The predictable peaks in pricing every twelve months

\footnotetext{
${ }^{1}$ U.S. Energy Information Administration (2015) [http://www.eia.gov/electricity/data.cfm]
} 
closely align with a crude, out-of-sample seasonal predictor of each calendar month's mean spread estimated in a non-overlapping sample from 1987-1998 (the dotted line).

Although seasonal volumes could easily be explained by coordinated variation in supply and demand, the predictability in market interest rates raises intriguing questions about borrower and lender behavior. What kind of firms rationally borrow in high priced periods as opposed to moving their demand to less expensive months? What prevents lender competition from smoothing out the seasonal markups that we observe? Answering these questions can provide broader insights into the behavior of borrowers and lenders.

From the borrower's perspective, we begin by noting that, if firms perceive predictable and meaningful variation in risk-adjusted credit spreads, this should alter their issuance strategy. Thus one immediate challenge of the paper is to decompose seasonality into the underlying seasonal markups and compositional effects based on borrowers' best response to those seasonal markups. By way of analogy, if the cost of calling a plumber on Sunday night is expensive, Sunday night service calls will be different than those which occur Monday morning. The inability of customers to wait until Monday and the difficulty of anticipating the problem may be related to the severity of the plumbing problem. A predictable change in the markup over time will lead to corresponding variation in the types of plumbing problems requiring repair, as customer behavior responds to pricing. Of equal interest is the underlying time variation in pricing and its effect (or the limitations of its effect) on customer behavior.

Not unlike a plumber’s Sunday service charge, we find evidence of an economically significant seasonal markup when comparing like firms, controlling for credit risk and project type. We also find that the markup appears to drive strategic timing of issuance by firms within the year. Higher credit quality firms time the market to take advantage of cheap issuance 
seasons, whereas weaker credits are relatively more prone to issuance during expensive seasons. This behavioral response by borrowers to seasonal pricing drives important selection effects in the data that we need to control for, but also implies that firms perceive seasonality as economically important.

The firms that borrow in the expensive months are notable along a number of dimensions beyond credit quality. Their projects appear to be less predictable, their cost of storing capital more expensive, and their credit demand more urgent (i.e. their projects are less deferrable). These imperfections in the ability to intertemporally substitute, forwards or backwards, are more pronounced in weaker firms and allow lenders to earn seasonal markups. Whereas higher credit quality firms can borrow on a precautionary basis and thus largely time the market based on pricing instead of the arrival of investment opportunities, weaker credits appear to borrow on an as-needed basis and therefore sometimes have urgent funding needs appear in expensive months.

Even if the movement of borrowers out of expensive months is not enough to eliminate the seasonal pricing we find, bank behavior could be. Thus for the seasonal pattern we observe to persist we need to explain why the actions of lenders facing predictable variation in lending rates have not eliminated the seasonal pattern and what this implies about bank competition. In a competitive lending environment with constant costs, seasonality should disappear, as lenders shift supply to months with larger markups. To reconcile lenders' behavior with the data, we draw from the well-developed literature on strategic temporal pricing, beginning with models of retail sales by Varian (1980) and intertemporal price discrimination by Stokey $(1979,1981)$. In particular, our analysis is informed by a model of sales proposed by Conlisk, Gerstner, and Sobel (1984). They suggest that a monopolist seller facing the continuous arrival of buyers with varying reservation prices will optimally choose a predictable cyclical price path: high prices 
followed by recurrent discounting ("sales”). Intuitively, this pricing allows customers with less urgent needs and perhaps lower willingness-to-pay to time their purchases to coincide with cheap seasons. Those customers with higher willingness-to-pay (and possibly less patience) will find it costly to delay their purchase and can thus be captured at higher prices. Both the predicted seasonal pattern and the suggested sorting behavior based on borrowers' urgency of need across seasons appear largely consistent with our findings.

While Conlisk, Gerstner, and Sobel's model is based on a monopolistic market, the syndicated loan market is better characterized as an oligopoly of large banks that set terms for the majority of transactions, along with a competitive fringe of smaller bank and non-bank lenders. Given this structure, the repeated interaction and public nature of the syndicated loan market will be necessary to enforce strategic interaction. In addition to matching the broad predictions of the Conlisk, Gerstner, and Sobel model to our data, we will show the role that competition in the syndicated lending market plays in effecting the seasonal patterns.

We are able to show that changes in concentration in the syndicated market across time (time-series variation) and across industries (cross-sectional variation) are strongly associated with changes in seasonality; the greater the concentration, the greater the seasonal variation from peak to trough. We also show the importance of repeated interaction in enforcing a cooperative equilibrium. During seasonal spikes in interest rates, small outsider lenders "elephant hunt", courting and winning the business of large investment-grade borrowers usually served by the top banks. The seasonal entry by fringe lenders drives the counterintuitive pattern of decreased measures of lender concentration during high priced periods.

Our findings and interpretation draw from a wide range of distinct literatures. While ours is the first full accounting of seasonal patterns in modern credit markets, it follows a number of 
papers on turn of the century credit seasonality driven by agricultural demand, the role of the Federal Reserve Bank in stabilizing seasonal prices, and the link between seasonal cycles and business cycles (Miron (1996)). Our paper shows that seasonal effects remain important and, moreover, are highly correlated with firm and loan characteristics. As a practical matter, in some situations it may be appropriate to control for seasonal effects with month of year fixed effects (Firestone and Rezende (2015) give a recent example). ${ }^{2}$

The broader interpretation of our findings as evidence on rate setting behavior among firms with market power, meanwhile, is informed by work on imperfect price competition and in particular, models of dynamic pricing strategies. Evidence of intertemporal price discrimination has been largely limited to the retail setting. We show that the mechanisms that allow sellers to separate high and low willingness-to-pay retail customers are similar for corporate customers. The importance of borrowers' cost of storing financial capital, for example, mirrors Hendel and Nevo's (2013) evidence that variation in soda shoppers' capacity to stockpile for the future separates customers based on price sensitivity. Similarly, borrowers with urgent needs arising in expensive seasons face the same problem as the eager video game purchasers in Nair (2007), who are charged a premium based on their inability to wait for falling prices.

Meanwhile, given the longstanding debate about the costs and benefits of bank competition, this industry is a particularly important setting to think about the pricing effects of imperfect competition. Our findings suggest that banks with market power can earn rents based on strategic variation in interest rates over time, as opposed to using a more traditional static

\footnotetext{
${ }^{2}$ One must be careful, however, to not blindly absorb the seasonal variation with dummies, as this may be part of the phenomenon a researcher is documenting. As we will show in this paper, both borrowers and lenders respond to differential pricing across the year. In light of our finding, how researchers should control for seasonality is context specific.
} 
restriction in loan quantities to raise interest rates (for an application of strategic variation in interest rates over the life of small firms see Petersen and Rajan (1995)). This suggests policy implications which are distinct from those of the prior literature on bank deregulation and competition.

The paper begins with a short description of the data and shows the seasonal pattern in the next section. With the seasonal pattern established, we then examine borrowers' issuance and investment activity in light of the seasonal effect. Finally, we explore how competition in the lending environment interacts with seasonality under the hypothesis that seasonal pricing arises as an optimal pricing strategy under imperfect competition.

\section{Data description and summary statistics}

We need loan-level detail, including borrower and lender information, to shed light on the behavior that gives rise to seasonality. We thus focus our analysis on Thompson Reuter's DealScan database. Loans are recorded in the data as of the effective date of the facility, usually the first date that funds are available for drawdown (e.g. the closing date), as distinct from data available from the Federal Reserve which records loans, and their corresponding interest rates, as of the date of drawdown, irrespective of when lenders commit to the terms governing that loan (which may have been months or years prior). ${ }^{3}$ The seasonality we find should therefore be interpreted as predictable variation in the outcome of negotiations between borrowers and lenders regarding the future availability and pricing of committed liquidity. One cost of relying on the DealScan data is that its coverage is primarily limited to the syndicated loan market. Although there is some information on large bilateral facilities—loans between a single bank and

\footnotetext{
${ }^{3}$ For example, Ivashina and Scharfstein (2010) show significant growth in loan volumes at the onset of the lending crisis due to borrowers drawing down on committed facilities, while new loan originations came to a standstill.
} 
borrower-lenders have little incentive to report details on privately negotiated loans. Information on bilateral credit is restricted to what can be found in borrowers' public disclosures.

Throughout our analysis, we use the facility start date-typically reported as the effective date of the loan facility —as the time stamp on the loan. Because of time spent in syndication and documentation, this is a lagged measure of the actual date on which the lead bank (and/or the syndicate) and the borrower agreed upon loan terms. For a small portion of the sample, the date on which the lead arranger received a formal mandate to syndicate the loan is reported. Using this date, we find that the peak interest rate season occurs for loans mandated in December and July, as opposed to February and August. Other than the lag, the pattern in interest rates is similar. ${ }^{4}$

Our measurement of prices and quantities focuses on two commonly used variables-Allin-spread and Facility Amount. Facility Amount refers to the amount of a term loan or the maximum amount a borrower can borrow under a revolving credit facility. The median facility amount for the full DealScan sample (from 1981 to 2012) is $\$ 67$ million, consistent with the large size of the average borrower in the syndicated lending market, a point we'll return to in a moment. All-in-spread is the spread over a floating base rate (usually 3 or 6 month LIBOR) that borrowers will pay on any drawdowns on the facility, plus any recurring transaction fees. This is an admittedly incomplete measure of the total payments that go to the lender. It does not include commitment fees paid to lenders on the undrawn amounts available, nor does it include any upfront fees common to these transactions. It is also a static measure of interest rate that reflects neither contingencies for step-ups or step-downs based on borrower condition nor the expectation of renegotiations following covenant violations.

\footnotetext{
${ }^{4}$ Thanks to Victoria Ivashina for pointing out the availability of this data.
} 
With these caveats in mind, we interpret All-in-spread as a proxy for the yield required by lenders. Appendix A provides evidence that the general seasonality in interest rates described using All-in-spread is consistent with similar patterns in both upfront fees (for transactions that report this variable) and commitment fees (for facilities with revolving loan components). The median All-in-spread reported in the data is 250 basis points; the mean is 254 .

As we mentioned above, the DealScan database covers primarily large borrowers. For the portion of the sample that we match to Compustat with a matching file provided by Roberts and Chava (2008), the median facility was to a borrower with assets of $\$ 984$ million (reported in 2012 dollars). Lending in the sample is likewise dominated by a handful of large banks. Ranking lenders by the volume of loans arranged in the prior year, the top 10 banks led 70\% of total issuance volume on average, although, as we will see later in the paper, this market structure has significant time series variation.

The summary statistics of primary interest to us, however, relate to the conditional distribution of interest rates and loan volumes by calendar month of the borrowing. Figure 2 plots the average monthly loan spread at the time of loan issuance as reported by DealScan from 1987 through 2012. The monthly means line up closely with the peaks and troughs observed in Figure 1, with May and October issuance predictably 20 basis points cheaper than pricing peaks in January/February and August. Meanwhile, Figure 3 plots these predicted seasonal spreadsalso estimated over the entire sample-against the average monthly issuance volume and the average number of transactions for each of the 12 months. Similar to their business cycle frequency counterparts, seasonal credit cycles have their highest interest rates during periods of reduced issuance volume, suggestive of a recurrent supply shock tracing out a demand curve. 
Table 1 formalizes the test of seasonality by collapsing loan level spreads into monthly averages and loan volumes into the log of monthly sums. This information is used to generate time series data on prices and quantities with a "month-year" as the unit of observation. (We later demonstrate the seasonal effect using loan-level observations). To test for seasonality, we fit the time series observations to models with dummy variables for each calendar month and either year dummies or autoregressive terms to capture business cycle variation in interest rates and issuance volumes. We then test for the equality of monthly dummy coefficients. The time series approach is attractive in that it allows for a natural treatment of the standard errors, which can be estimated following Newey and West (1987) with a rolling 12 month lag. Columns 1 and 2 use a simple model with month and year dummies to test the presence of calendar month seasonality on spreads and volumes. Columns 3 and 4 estimate an AR model with lags 1 through 4, in addition to a 12 month lag. ${ }^{5}$

In each of our time series tests, we strongly reject the null hypothesis that the coefficients on the 12 calendar month dummies are equal at the $1 \%$ level. ${ }^{6}$ In unreported results, we rerun both tests in first differences and find the monthly effects are both significant and significantly different from each other, even after removing possible unit roots in spreads and volumes.

\footnotetext{
${ }^{5}$ The inclusion of a 12 month lag in addition to 12 calendar month dummies distinguishes the seasonality as being fixed around calendar months as opposed to being driven by last year's interest rate. For example, Heston and Sadka (2008) and Keloharju, Linnainmaa, and Nyberg (2013) find individual stocks or well diversified equity portfolios that do well in the current month are also likely to have a higher than average monthly return for the month falling 12 months in the future (or 24 months, 36 months etc.). Unlike our effect, it is not based on the calendar.

${ }^{6}$ Our analysis will focus on the seasonality in the interest rate spread over the benchmark (usually LIBOR). Although our focus is on the interest rate spread in the syndicated loan market, we checked for seasonality in three market interest rates: LIBOR (F-statistic $=0.46$, p-value $=0.92$ ), the Baa-Aaa bond spread (F-statistic $=0.57$, pvalue $=0.85$ ), and the CDS spread (F-statistic $=0.28$, $p$-value $=0.99$ ). The F-statistics and associated $p$-values are reported in parenthesis (see Table 1 - columns 5-7 for details). None of the three series exhibit a calendar month seasonal pattern during our sample period. Over a longer time series, Kamstra, Kramer, and Levi (2015) show seasonal patterns in treasury returns, but the pattern does not coincide with the seasonal effects in loan spreads.
} 
Meanwhile, the magnitude and timing of the cycle are generally consistent with the pattern seen in Figure 2: local pricing peaks in late summer and winter, and troughs in early summer and fall.

The pattern observed in seasonal quantities is easy enough to reconcile with a story about labor market holidays, the timing of which is roughly coincident with low periods of issuance. Both CFOs and credit analysts alike have incentives to coordinate their leisure consumption at the same time, such that productivity is maximized during the rest of the year. Thus, we might expect low volumes for transactions starting in late December, and closing in January and February, with a similar pattern in the summer months. Harder to explain is the sustained seasonality in prices under the null hypothesis that 1) firms can costlessly move their capital issuance to low-priced periods, either by timing investment projects or by storing capital when it is offered at a discount; and 2) lenders should have the incentive to lend more in periods when spreads are more attractive until the pricing patterns are eliminated. We tackle the timing of

firms' borrowing behavior given seasonality in Section III, and follow by investigating the incentives of lenders to compete away seasonal spreads in Section IV.

\section{Borrowers and seasonality}

Taking the seasonal pattern in spreads as given, what prevents borrowers from shifting their issuance from high into low priced periods until the pattern dissipates? For example, borrowers might raise precautionary funding during cheap periods, even when they have limited need, in order to avoid the high-rate season. Alternatively, they might delay projects that arise in expensive times. Note, however, the costs of taking either action in response to seasonal effects may vary by firm type. Returning to the example of weekend plumbing repairs discussed in the introduction, the inability of a customer to wait (or perhaps to anticipate and resolve plumbing 
issues with early maintenance and repair) may be correlated with the severity of the problem and related repair costs, independent of the markup charged for a weekend consult. In the loan market setting, the firms who fail to anticipate or can't delay funding needs during expensive seasons are, by definition, different from those who hedge their financing needs in advance or opt to forgo high-priced borrowings. To the extent that those differences correlate with firm risk, even a small seasonal pattern may drive large selection effects. Thus, part of our challenge in this paper is breaking down the relative magnitudes of, as well as the economic drivers behind, the two related effects.

To isolate variation in borrowing costs over the seasons from the associated selection effects, we focus on samples of borrowers for whom creditworthiness is relatively observable or for whom we have direct measures of risk premiums from outside the bank market. Table 2 uses long-term credit ratings from Standard and Poor's and firm characteristics as a starting point for pinning down borrower risk. Specifically, we estimate the model

$$
\text { AllinSpread }_{i, t}=\delta_{t}+\gamma_{\text {industry }}+\lambda \text { Seasonal }_{t}+\theta \text { Rating }_{i, t}+\beta X_{i, t}+\varepsilon_{i, t}
$$

where Seasonal is the variable by which we parameterize the seasonal component of AllinSpreads (details below), $\theta$ is a dummy for each long-term debt rating category, $\delta_{t}$ and $\gamma_{\text {industry }}$ are year and industry dummies, and $X$ represents a vector of firm- and deal-level controls. ${ }^{7}$ The goal of equation (1) is to identify the extent to which variation in borrowing costs is attributable to differences in borrower quality over the cycle as opposed to a true shift in borrowing cost, holding risk constant. For now, the analysis assumes that credit ratings provide a timely and complete picture of borrower risk.

\footnotetext{
${ }^{7}$ We restrict ourselves to package level observations within DealScan (a package reflects a group of facilities sold to an overlapping syndicate and governed by the same contract) under the assumption they are negotiated at the same time. Because spreads and maturity may vary within a package, we use the mean spread and the maximum maturity in regressions hereafter.
} 
Because business cycle variation is a first order determinant of loan spread, we include year fixed effects. (More granular time specifications would soak up the seasonal variation we're interested in.) Time fixed effects also include an indicator for the second half of 2008 (in addition to a 2008 dummy) to account for high spreads on new loans issued in the midst of the global economic crisis. Other model controls include firm size (log book value of assets), operating profit as a percentage of assets, book leverage, and tangibility of assets, defined as property, plant, and equipment divided by total book assets. We also use 17 Fama-French industry dummies (Fama and French (1997)) to soak up industry factors that might correlate with issuance timing. At the deal level, we control for the maturity of the debt, whether or not DealScan reports any part of the loan as being secured by collateral, and the reported deal type. ${ }^{8}$

We present two distinct approaches to modeling the seasonal effect (Seasonal). First, we include dummy variables for both expensive and cheap periods. We define each season as the three month periods of locally high (low) interest rates, and correspondingly (low) high issuance volumes. Figure 2 and Table 1 both point to local interest rate spikes during the winter in January and February, and during the summer, in August. Meanwhile, seasonal low points in interest rates occur in late spring and fall, specifically May, June, and October. Thus we define the expensive issuance season as the months January, February, and August and the cheap season as the months May, June, and October. ${ }^{9}$ The coefficients on the dummy variables for these

\footnotetext{
${ }^{8}$ Deal type controls include dummies for the most common transaction types: corporate purposes, working capital, CP backup, debt repayment, takeover (including LBO's and acquisitions lines), and other. Loan spreads, along with all continuous control variables, are all winsorized at the $1 \%$ level.

${ }^{9}$ In choosing the expensive season months, note that we chose local peaks in interest rates that also coincided with reduced volumes (this is easiest to see in the interest rate/loan volume scatter plots in Figure 3). These months are most consistent with a supply shock coming from banks which will be the subject of the analysis in the second half of the paper. Nonetheless, in Appendix B, we replicate key results using January/February/March as the expensive season with similar results.
} 
seasons capture the mean increase/decrease in spread after conditioning out the effects of changing borrower quality and differences in loan terms.

Our second measure of seasonal effects uses a sample of firms from DealScan that cannot be matched to Compustat—and therefore are not included in the initial regressions — to estimate a predicted seasonal spread (monthly average). This seasonal prediction is then included as a right-hand side variable in our regressions. Assuming the samples are i.i.d., without any controls, we would expect a coefficient on the seasonal variable equal to unity. To the extent that seasonal variation in firm or deal characteristics contributes to seasonality in rates, the coefficient will attenuate towards zero as controls are added. In a complete specification of all covariates with related seasonal components, the coefficient would be interpretable as the fraction of the total seasonal effect that is not due to selection.

Using the estimated seasonal effect from the holdout sample ensures that our tests are not biased by prior information about seasonality. Moreover, it prevents individual transactions in our regressions from influencing the estimated seasonal effect to be used on the right-hand side. Including a single variable to capture seasonality also gives structure to the seasonality. As an alternative, including 12 monthly dummies might allow us to test for some version of seasonality, but not tie our hands to specifically test whether or not the pattern we've observed and documented in unconditional tests holds up after conditioning on changing borrower risk profiles. Finally it gives us a direct measure of the extent to which seasonality is linked to selection rather than pure price shocks.

Finally, our regressions cluster standard errors at both the firm and the monthly level. Given the general rule of thumb that clustering along the larger dimension provides a more robust correlation structure among errors, it might seem preferable to cluster at the yearly level 
instead. However, in our most comprehensive specifications, we find that clustering at the yearly level produces standard errors that are considerably smaller than those obtained by monthly clustering. ${ }^{10}$

Columns 1-3 in Table 2 report the mean variation in loan spreads across seasons under a variety of controls with the benchmark case of only time dummies reported in column 1 and a seasonal spread of 19 basis points. Including loan purpose, maturity, and security controls, we see that loans closed in January, February, and August are assigned interest rates 11 basis point higher than loans closed during May, June, and July. The difference, reported at the bottom of the table, is significant at the $1 \%$ level. This is consistent with seasonal variation in borrower need for different types of financing - a hypothesis we explore further in tables 4 and 5 . Meanwhile, in columns 3 and 4, the seasonal effect attenuates to between 6 and 7 bps when we add the full set of controls to pin down borrower creditworthiness. These controls include firm debt ratings (recall only rated firms are included in the regression), Compustat controls for size, profitability, leverage, asset tangibility, and even firm fixed effects. While the shrinking magnitude of seasonality after conditioning out firm and loan characteristics tells us that seasonal variation in borrower and loan type is an important part of rate seasonality, all else equal, observationally identical borrowers receive different credit terms depending on their season of need. ${ }^{11}$

\footnotetext{
${ }^{10} \mathrm{~A}$ possible reason is the small sample bias that arises from clustering on a dimension that has too few clusters (years). This becomes particularly problematic for the CDS sample used in the second part of Table 2 (and discussed in the following paragraphs) which includes less than 10 years of data (see Petersen 2009).

${ }^{11}$ The documented seasonal variation in loan spreads is based on the calendar, not fiscal, year. This raises the question of whether the pattern we show is truly a fiscal year phenomenon. Empirically distinguishing between a calendar and fiscal year pattern is difficult due to the multi-collinearity of the monthly dummies based on the calendar and fiscal year. In our sample, 76\% of firms have a December fiscal year end. To test whether the seasonal pattern is different for firms with a non-December fiscal year-end we include an additional 11 dummy variables. The 11 dummy variables are equal to one for the second through twelfth month of the fiscal year if the firm has a non-
} 
Columns 5 and 6 repeat the specifications of 3 and 4, replacing season dummies with the seasonal prediction from the non-Compustat firm holdout sample, eliminating concerns about bias in our inference based on our prior knowledge of seasonality. Comparing firms with the same rating and even the same firm over time (in column 6), we find that $50-60 \%$ of the seasonal magnitude observed in the holdout sample is still evident after controlling for firm and loan characteristics. It is worth noting the similarity in coefficient estimates and $\mathrm{R}^{2}$ between columns (3) and (5) and columns (4) and (6). Although we control for seasonality in two distinct waysdummy variables for expensive and cheap periods in columns (3) and (4), the holdout sample in columns (5) and (6) — the data display essentially the same patterns. Appendix B finds similar effects after replicating these results over a variety of subsamples and alternative specifications.

After controlling for observable firm and loan characteristics, the magnitude of a 6 basis point pure seasonal effect is considerably smaller than the original $15-20$ basis points observed unconditionally. Yet in the forthcoming tables, we'll present evidence that this is sufficient to induce both firms and banks to alter their behavior, implicitly suggesting the economic significance of the seasonal effect. Although 6 bps may appear small relative to the total variation in spreads across different classes of borrowers and loan types, it is sizable relative to the typical variation in spreads faced by a particular firm with a predetermined use of proceeds. For example, excluding borrowings arranged in the depth of the financial crisis, the median absolute value change in spreads experienced by a repeat borrower returning to the market for the same deal purpose is just 15 bps; the modal firm experiences no change in spread. Thus, a 6

December fiscal year end and zero otherwise. Thus for a firm with a March fiscal year end that closes their loan during March the fiscal month 12 dummy would be equal to one.

We re-estimated column (1) through (4) in Table 2 and found the inclusion of these fiscal month dummy variables had very little effect on the estimated difference between the loan spread in the expensive and cheap seasons. The expensive-cheap spread is 18.55 (p-value $<0.01$ ) in column (1) and 5.94 (p-value=0.019) in column (4). These numbers are almost identical to what we report in Table 2. The F-statistics that the fiscal year monthly dummies are jointly zero is not statistically significant. The p-value is 0.57 in column (1) and 0.82 in column (4). 
bps seasonal difference in markups is non-trivial when compared to other sources of variation in spreads facing a typical borrower. From the lender's perspective, it's helpful to benchmark the seasonal markup against lead arranger fees-that is, the fees that lead banks receive for structuring and syndicating these transactions, given that both reflect compensation for services and not risk. These fees were just 16 bps for US investment grade loans as of 2011 and averaged 35 bps globally (Thompson Reuters 2011 Syndicated Loan League Tables). If the top banks are eager to exert time, effort, and reputational capital to arrange a large syndicated loan for just 1635 bps, then 6 bps is presumably non-trivial for lenders.

One concern with the ratings sample used in columns 1-6 is that ratings are an incomplete or imperfect measure of borrower risk. Specifically, the risk captured by ratings may not map one-to-one into loan spreads. Suppose market participants possess better information than rating agencies. Any seasonality in unobserved borrower creditworthiness may have a substantial effect on loan spreads but not be captured by controls. Moreover, limiting spread determination to default frequency ignores the role of state pricing; the state of nature in which a loan defaults should also dictate its expected return. Thus, in Table 2, columns 7 and 8, we focus on firms for which credit default swaps are quoted in the month in which each loan in our sample is issued. We use the reported CDS spread as a control for the credit risk associated with a borrower. CDS spreads provide a useful alternative to ratings, as the spread on credit default swaps should impound any information the market, and thus bankers, have about the borrower. Moreover, because CDS spreads are themselves risk premiums, they control for both the probability of default and the covariance of expected cash flows on borrower loans/bonds with discount rates. Finally, after controlling for CDS spreads, we can dismiss the notion that, more broadly, risk 
premiums follow a predictable seasonal pattern, or at least that seasonal risky premiums drive seasonal loan spreads.

We use Markit data to match the merged DealScan/Compustat database to CDS spreads. Matching is based on borrower name. We only accept exact or very close matches to avoid ambiguity about firm identity. We end up with 2,064 loan transactions for which the borrower had a quoted CDS spread in the closing month for the loan. Markit reports quoted spreads for various maturities. We use the average 5-year spread reported during the closing month. In the rare event that the 5-year spread is missing, we default to reported 3- or 7-year spreads. With CDS spreads in place, we replace the model in equation (1) with the following specification:

$$
\text { AllinSpread }_{i, t}=\delta_{t}+\gamma_{\text {industry }}+\lambda \text { Seasonal }_{t}+\theta_{1} C D S+\theta_{2} C D^{2}+\beta X_{i, t}+\varepsilon_{i, t}
$$

We allow for a flexible functional form for the relation between loan spreads and CDS spreads, including both the level and the squared CDS spreads as controls in our regression. This nonlinear functional form is supported by our regression results, as well as visual inspection, which suggest the relation between loan spreads and CDS spreads is concave. Finally, because borrowers with traded CDS have substantially different transaction timelines than firms in the holdout sample (typically smaller, privately owned firms), the time between rate setting and loan closing impacts the timing of observed seasonality. To account for this, we shift back by two weeks the dates for the CDS sample so that CDS spreads will better reflect firm circumstances on the original negotiation dates. The 2-week adjustment is based on the mean difference in closing speed for borrowers in the CDS and holdout samples. It is estimated from the subsample of loans for which facility start date and mandate date are both reported in DealScan.

Due to the limited availability of the CDS spread data, our sample shrinks appreciably when we condition on its existence. However, supplementing the rating dummies (column 3) 
with the CDS spread and its square (column 7) again produces a similar estimate for the seasonal difference: 7 basis points. Finally, in column 8, the coefficient's influence on the out of sample seasonal effect is larger than before ( 0.73 versus 0.51$)$ but not significantly so, and it is still notably smaller than one. As before, the coefficient estimates and $\mathrm{R}^{2}$ are almost identical across both measures of seasonality.

Our interest in the reported results is twofold. First, note that loan seasonality is not solely a product of variation in borrower risk. Rather, the evidence suggests that, even with a variety of controls for the market price of a borrower's risk, lenders mark-up loans priced during the winter and summer, and provide discounted borrowings in the fall and late spring. Given that CDS spreads represent a natural baseline cost of credit for the borrower, the first result suggests that lenders' ability to generate rents from their specialized services varies within the calendar year. $^{12}$

Second, the attenuation in the seasonal effect after appropriately controlling for borrower risk implies that borrowers respond to seasonal lender markups by sorting into different periods in ways that correlate with their risk. Table 3 makes this point directly by estimating an ordered probit model of the season in which a borrower times its issuance, using logged CDS spreads as the right-hand side variable of interest. Season of issuance is coded as a -1 for cheap issuance seasons (low spreads), 1 for the expensive issuance season (high spreads), and 0 for the rest of

\footnotetext{
${ }^{12}$ After controlling for ratings-based, accounting-based, and even market-based measures of borrower risk, we've interpreted the residual spread between expensive and cheap seasons as a non-risk markup charged by lenders, making borrowing in January and February more expensive for the average borrower. The alternative explanation is that loans issued in these months are riskier in ways that we have not controlled for. Although we can never be certain we have the same information about risk that the borrowers and lenders have, we can take an alternative approach to answering this question. If the spread we find in Table 2 is unmeasured risk, then borrowing in January and February is not more expensive for borrowers, nor is it more lucrative for lenders. In this case, there is no incentive for borrowers to move their borrowing away from the expensive months. Nor is there any incentive for lender to try and poach loans in the expensive (more lucrative months). We find evidence of both behaviors and both are consistent with the spread we find being a differential markup opposed to a difference in unmeasured risk. We examine the behavior of borrowers at the end of this section and the behavior of lenders in Section IV.
} 
the year. We include year dummies, as well as controls for the end of the borrower's fiscal year and industry fixed effects, both of which may determine the choice of issuance season. The marginal effects reported in column 1 suggest that a move of one standard deviation in CDS spreads reduces the probability of issuing during the cheap season by $2.6 \%$ and increases the probability of an issuance during an expensive month by $2.0 \% .{ }^{13}$ Recall that, in Table 1 , we found that an index of dollar CDS spreads from 2001-2010 did not exhibit seasonality. Similarly, we found no seasonal pattern in Baa-Aaa spreads on seasoned bonds. Thus, it seems unlikely that seasonal variation in macroeconomic risk is driving the correlation between issuance season and firm risk. Instead, it seems more plausible that the covariation is driven by compositional effects.

Why issuers of different quality might sort into different seasons is open to a few interpretations. First, given the coordinated reduction in lending and borrowing during expensive periods, only borrowers in desperate need will seek financing. Thus, the act of borrowing itself may serve as a strong signal of the severity of borrower need, causing the lender to rationally update his belief about borrower risk. ${ }^{14} \mathrm{~A}$ related interpretation would be that the borrower received a severe and observable liquidity shock that caused both the urgent borrowing need and the deterioration in CDS spreads.

Either of the above interpretations would suggest that changes to borrower CDS, rather than the level of the CDS, should be linked to borrowing in expensive months. Column 2 of Table 3 finds little evidence of this link. In column 2, we replace logged CDS spreads with the

\footnotetext{
${ }^{13}$ Logged CDS spreads and changes in logged CDS spreads in Table 3 are standardized (demeaned and given unit variance) such that the marginal effect can be interpreted as the effect of a one standard deviation change in the variable of interest on the probability of issuance in a given season.

${ }^{14}$ This hypothesis would not fully explain the seasonality we find. The presumed new information about borrower risk revealed by the borrowing season should be reflected in CDS spreads. Table 2 showed that, even controlling for all priced information regarding the borrower's condition, banks charge a markup for their services during summer and winter.
} 
change in logged CDS spreads, where the difference in spreads is measured between the month of issuances and 6 months prior. We find the coefficient on CDS changes is positive, but not significant. Controlling for both the level and the change in spreads in column 3, only the level effect is correlated with issuance season. Replacing the backwards looking change in CDS spreads with a forward looking measure in column 4-the change in spreads from 6 months prior to 6 months after issuance-leaves the results essentially unchanged.

While we can clearly say that borrowers who tap the markets during expensive months tend to be riskier borrowers than those who take advantage of fall and late spring discounts, there is no evidence that the act of borrowing coincides with, or signals, credit deterioration. Rather, it seems that a fixed component of borrower risk plays a role in the timing of issuance.

This leads us to a second interpretation of the selection effects in which firms facing low costs of financing anticipate potential borrowing need during high-priced seasons and arrange for precautionary financing during "sales". Precautionary borrowing in the seasonal context is a straightforward extension of the literature on the use of lines of credit and excess cash to provide for unexpected investment opportunities. Lins, Servaes, and Tufano (2010), for example, suggest firms may pre-arrange lines of credit to make acquisitions on short notice. In the seasonal setting, we can imagine firms reserving their funding during cheap periods to lock-in rates in the event an investment opportunity arises.

However, there may be substantial variability in the cost of the option embedded in a line of credit (or alternatively, a funded loan invested in cash or liquid securities). In a ModiglianiMiller world, the discount rate for holding cash is the same for risky and riskless firms. However, when cash or lines of credit are retained for the purpose of making risky investment in the future, conditional on the investment opportunity arising, then the discount rate will depend 
on the riskiness of the universe of possible opportunities and the probability of each arising. Martin and Santomero (1997) show that firms that have a high variance associated with their investment opportunities face higher costs of securing precautionary funding and are therefore more likely to rely on spot borrowing markets as opportunities arise. If we think riskier firms face more uncertain growth paths, then we would expect to see low-risk firms issuing more in the late spring and fall, thereby leaving winter and summer for weaker credits who fund themselves in the spot market. Alternatively, firms with higher CDS spreads may face more severe hidden information or hidden action problems and therefore pay a larger dead weight cost of arranging precautionary financing than a firm that can be more easily be trusted to serve as a good steward of cash until the arrival of such a project. Either case will generate the variation in borrower quality we observe over the cycle.

Evidence on the precautionary nature of seasonal borrowing comes in two flavors. First, we can look at transactions during "sales” and see if borrower behavior - in particular, the use of credit lines and investment patterns - fits a model of precautionary issuance. Second, we want to examine borrowings done in expensive periods and question the extent to which these borrowers appear as if they are responding to unanticipated investment opportunities. We do this by looking at the drawdown and investment behavior of borrowers, as well the types of loans and the use of proceeds reported for borrowings over the course of different issuing seasons. ${ }^{15}$

Table 4 returns to the fully linked DealScan-Compustat sample and reports on the sources and uses of cash associated with new financings as a proportion of DealScan issuance activity

\footnotetext{
${ }^{15}$ An additional way to examine the motivations of firms in our sample is to examine individual cases. We thus searched the financial press and analysts reports of firms in our sample who borrowed in the expensive months. In the vast majority of cases, firms do not publicly disclose the reasons for their financing. In a few cases we were able to determine the motivation for the financing and why the firms were unable to predict their financial needs or postpone the investment project. Four examples are contained in Appendix C.
} 
during that quarter. Of interest is the extent to which firms actually borrow the funds available to them under new loan facilities, and how that depends on the season of loan issuance. For each borrower $\mathrm{x}$ quarter observation, we sum up the total volume of DealScan issuance reported and note the season of issuance. CheapSeason refers to issuers who arranged their financing during May, June, and October. ExpensiveSeason refers to January, February, and August. The base category reflects issuers who arranged financing during the rest of the year. Non-issuers or issuers who spread their borrowings across multiple seasons are then excluded from the sample. Also excluded from the sample are small borrowings (those which constitute less than $1 \%$ of the firm's total assets) and are therefore unlikely to be systematically related to changes in cash flows.

In columns 1 and 2, we focus on the change in cash attributable to new financing from the firm's statement of cash flows, scaled by the total volume of DealScan facilities closed during the quarter. We only observe loan commitments made in DealScan and not the extent to which borrowers actually borrowed from their facilities. Thus, cash flow from financing scaled by total issuance suggests the extent to which borrowers actually drew down the funding sources they arranged during the quarter in which they arranged it. That is, we track variation in the extent to which firms exercise the call option on funding embedded in a line of credit and how that variation depends on season of issuance. In columns 3 and 4, we then look to the percentage of funding allocated to new investments, again using net investment variables from the statement of cash flows.

In each case, the coefficient estimates reported for the variable CheapSeason (ExpensiveSeason) represent the mean difference in drawdown/investment activity observed for firms who issue during the cheap (expensive) season relative to those issuing during the rest of 
the year. As controls, we include the percentage of issuance that is flagged as a refinancing in DealScan or for which the primary purpose was flagged as debt repayment. We also control for cash flows from operations, derived from the borrower's statement of cash-flows. Finally, in addition to year dummies, we also include dummies for the fiscal quarter in which the issuance (and related cash flow from financing/investment) occurred. This accounts for the fact that firms may have seasonality in their fiscal reporting cycle that coincides with the loan market seasons. Columns 2, 4, 6, and 8 also include borrower fixed effects.

Focusing first on the results from columns 1 and 2, we immediately see a consistent pattern tying the extent to which funds are drawn to seasonal cost. Borrowers issuing during the expensive season draw down $2.4 \%$ more than those issuing in the cheapest season. This difference in cash from financings is significant at the 5\% level. The effect is unchanged when borrower fixed effects are included as controls. Thus, a given borrower will draw down more of the cash available from a loan facility when the loan is originated during an expensive, as opposed to cheap period.

We observe a similar result when comparing the investment activities of borrowers based on issuance season. Specifically, borrowers who borrow during discount periods spend 2-3\% less of the commitments raised on investment than when they borrower during expensive months. This post-issuance behavior is consistent with high quality spring and fall issuers responding to cheap funds by raising precautionary credit in case financing needs arise, and lower quality issuers deferring borrowings until a clear need for disbursement and spending is identified, even if it means borrowing at higher rates.

The results presented in columns 1 through 4 would seem to suggest that borrowers do move in response to seasonal price variation. In particular, firms seem to take advantage of sales 
periods by issuing, even when their apparent need (at least their ex-post realized need) for funding is low. Meanwhile, the selection effects apparent in Tables 2 and 3 suggest that sales periods are populated by firms that enjoy low cost of credit regardless of season. Putting these two effects together, it's tempting to think that the precautionary borrowing motive is stronger for firms with lower borrowing costs, or rather less enticing for firms facing high costs. Returning to the commodities examples from the introduction, commodity buyers need to have access to efficient "storage" for the commodity to arbitrage seasonal spot prices. By way of analogy, if weaker credits are less efficient at storing capital because their net cost of carry is higher, then their ability to move their demand may be limited.

To verify this, we not only need to see that high credit quality firms are more prevalent issuers during cheap periods (as shown in Tables 2 and 3) and that issuance during sales tends to be more precautionary in nature (columns 1-4 of Table 4), but we also need the interaction of the two effects. That is, low-interest-rate firms will take advantage of sales with precautionary issuance while high-interest-rate firms ignore sales and issue on an as-needed basis. Columns 5 through 8 test this idea with the inclusion of interaction terms between issuance season and a dummy for low vs. high interest rate borrowers. We classify high interest rate borrowers as those in the top quartile of firms based on the average interest rate spread paid over the DealScan-Compustat linked sample. We classify low interest rate borrowers as their complement. For clarity of presentation, we report our regression results based on interactions with a low interest rate dummy.

The evidence appears consistent with the theory that precautionary motives are substantially weaker among high-interest-rate borrowers. Specifically, with either cash flow from financing or investment/issuance amount on the left-hand side, there is no difference in 
drawdown or investment behavior across seasons for high-interest-rate borrowers. ExpensiveSeason - CheapSeason estimates are not statistically or economically distinct from zero. Instead, it is low-rate borrowers that drive the average effects reported in columns 1-4. The interaction of season of issuance effects and funding cost-(ExpensiveSeason CheapSeason) $X$ LowRateBorrower-represents the differential sensitivity to issuance season effects between high and low rate borrowers. We find the interactions range from 5.1\%-5.4\% for drawdown behavior and $4.1-4.9 \%$ for investment behavior; these are significant at the $5-10 \%$ level, depending on the specification. Thus, the precautionary issuance behavior is significantly different (in that it is not evident at all) for firms that face a high cost of capital throughout the year. This suggests that a "storage cost" hypothesis is at least one mechanism preventing borrowers from fully moving their financing needs to low cost periods. ${ }^{16}$

Even with some firms issuing on a precautionary basis, some non-deferrable and unanticipated projects will fall into high-interest-rate periods. In Table 4, we showed these loans were associated with higher level of drawdown and investment. To get a clearer sense of the types of non-deferrable projects being funded during expensive seasons, Table 5 reports the use of proceeds and deal types for the different seasons. The top panel tabulates the number of deals by time of issuance (rows) and the use of proceeds (columns) variable reported in DealScan. We also report the percentage of deals linked to each use of proceeds within a given season. Meanwhile, the final row reports an overall chi-squared test of the null hypothesis that the distribution of deal purpose is independent of issuance season, as well as each column's contribution to that statistic. To narrow our discussion, we'll focus on relatively large

\footnotetext{
${ }^{16}$ Regressions without borrower fixed effects also report the coefficient on the indicator for low interest rate borrowers (otherwise absorbed by fixed effects). That coefficient is negative and significant for cash flows from financing and investment, consistent with high interest rate borrowers being unconditionally less likely to engage in precautionary borrowing, regardless of season.
} 
contributors to the overall differences in the distribution of deal type over different seasons: commercial paper backups, takeover and LBO deals, and debt repayment. ${ }^{17}$

Unsurprisingly, we see that regular, anticipatable financing needs are typically taken care of during sales periods. Specifically, commercial paper back-up lines used to support the issuance of short-term notes by highly rated borrowers tend to happen during the cheap season. Debt repayments or refinancing also tend to happen during cheap seasons. In each case, the financing need is easy to anticipate and scheduled in advance. In contrast, the table shows that takeovers and targeted acquisition activity seem to be concentrated during expensive months. Unlike investment in new equipment or inventory, acquisition financings are likely to be timesensitive and non-deferrable. They also may arise unexpectedly, as rival firms may put a target “in play” at any time, forcing bidders to arrange financing on short notice. We give several such examples in Appendix C.

The second panel of Table 5 repeats the analysis based on the loan type variable reported in DealScan. Consistent with precautionary borrowing, we see that the seasons of cheap issuance are more frequently populated by short-term revolvers that charge only a commitment fee if the facility is unused. In contrast, during the expensive season, term loans, typically funded immediately at deal closing, are more likely. While a small percentage of total

\footnotetext{
${ }^{17}$ The Chi-squared test statistic in the Table 5 references a Pearson chi-squared test of row-column independence. It is calculated by summing the squared deviations of actual frequency counts for each column $\mathrm{x}$ row cell from its expected frequency under column-row independence, in each case scaled by the same expected frequency. The degrees of freedom for the resulting statistic are equal to (number of rows minus 1 ) x (number of columns minus 1). The numbers at the bottom of each column represent the contribution of the column to the overall Chi-squared statistic. The superscript associated with that number references the p-value of a test that the probability of a given Deal Purpose vs any other Deal Purpose is independent of season (i.e. the F-test from a regression of a Deal Purpose dummy on seasonal dummies). Standard errors used in calculating p-values are clustered by firm and month.
} 
financings, the significant increase in bridge financing is also consistent with an urgency of need during more costly months. ${ }^{18}$

Returning to the question of why the ability of firms to time their issuance is insufficient to quash the documented variation in credit cost, we've suggested two possible costs of adjustment. First, we showed that only firms with already low interest rates seem to take advantage of the sales, perhaps because cost of storing capital is too high for riskier credits. Second, even with some firms arranging precautionary financing during sales, some high value, non-deferrable projects beyond the scope of pre-arranged lines of credit and cash may still arise during high cost periods.

Before continuing with the next obvious question—why don't banks compete away seasonality—it's worth foreshadowing our response by pointing out that the borrower reaction to cyclical variation effectively sorts firms into two periods based on degree and urgency of funding needs. Low need/precautionary debt issuance occurs during sales and higher need/higher urgency issuance occurs during the rest of the year. In the next section, we consider the possible usefulness of this equilibrium sorting mechanism to banks who would optimally like to set an interest rate schedule that charges each borrower based precisely on their willingness-to-pay, and the resulting disincentives to compete the pattern away.

\section{Lenders and seasonality}

In the prior section, after benchmarking borrowers during high and low priced seasons against firms of equivalent creditworthiness, we showed that lending spreads are considerably more favorable to banks during certain times of the year (see Table 2). Having documented the

\footnotetext{
${ }^{18}$ Bridge loans refer to short-term loans for longer term projects. They are designed to be refinanced with longer term debt when market conditions improve.
} 
borrower response to these seasonal fluctuations, we now consider why lenders don't simply shift their production into periods of higher markups until the seasonal pattern disappears.

One possible explanation is that the cost, or possibly the efficiency, of labor varies enough across the seasons that even though prices fluctuate, lender profits are constant, dissuading further lender entry into summer and winter months. ${ }^{19}$ This labor cost hypothesis posits that summer/winter loans are more expensive because loan officers' marginal cost of being in the office is higher during these periods and these costs are passed on to the borrower. The intuitive appeal of this argument is bolstered by the close correspondence between peak pricing periods and traditional vacation periods for workers in the financial sector. It is tempting, for example, to imagine that a banker who works over Christmas break to close a loan in January or forgoes a scheduled trip to the Grand Canyon with her family during July or August might be entitled to additional bonus compensation. Alternatively, labor may simply be less productive during summer months and thus require more labor input on a per deal basis. If, for example, it takes the lead arranger of a syndicated loan twice as long to coordinate participant banks as a result of heavy vacationing, the cost per loan will rise, even though the cost per unit of labor is constant.

The labor costs hypothesis, however, seems less plausible when we hold it up against the magnitude of the seasonal component of interest costs, including spreads and fees. Suppose that the seasonal spread is driven completely by variation in labor costs. As an example, take the 10 bps spread between interest rates in August, an expensive summer month, and the cheapest month of the year, May. Under the labor costs hypothesis, the extra wages that must have been

\footnotetext{
${ }^{19}$ We showed in Table 1 that there is little evidence in support of seasonality in base rates like LIBOR during our time period, suggesting the other non-labor input in the bank's production function does not drive seasonality in loan rates.
} 
paid seasonally to bank officers in August are equal to the 10 bps difference in interest rate times the quantity lent. Repeat this for the remaining 11 months of the year and we can come up with annual seasonal component of wages that banks would have to pay their workers to generate the effect on interest rates that we observe.

To estimate the implied labor costs, and thus better understand the plausibility of this supply driven explanation for seasonal pricing, we need to make a handful of assumptions. First, we need to make an assumption about how long a seasonally expensive loan is outstanding and thus, for how long the additional seasonal spread accrues to the lender (and in turn, the worker). Although the average loan has a 4.5 year maturity, we assume the excess costs of borrowing in an expensive month are born for only one year. Because most loans have upfront, one-time costs associated with issuance, this is likely to be conservative, given that even if borrowers quickly refinanced expensive period borrowings in the next cheap season, they would be forced to bear the cost of repeated upfront fees. Obviously, if borrowers leave seasonally expensive loans in place for more than one year, the seasonal costs are higher. We also consider fees, some of which are only paid on drawn or undrawn portions of revolving lines of credit. In allocating costs to drawn and undrawn portions of a line of credit, we assume lines of credit are drawn $33 \%$ of the time. ${ }^{20}$ Based on these assumptions, we calculate the borrower's cost of funds above and beyond LIBOR as the upfront fee for a loan plus $33 \%$ of the spread plus $66 \%$ of the commitment fee paid on undrawn amounts for lines of credit. We also include upfront fees plus spreads for term loans, which are assumed to be fully drawn.

\footnotetext{
${ }^{20}$ Although these number vary from year to year, a sampling of the Federal Reserve's Shared National Credit Reports suggest outstanding loans represent $30-50 \%$ of total commitments. Assuming $50 \%$ of committed lines are drawn on average (or ignoring commitment fees completely and assuming lines of credit are always fully drawn) drives up seasonal costs and thus creates a higher hurdle for the labor costs hypothesis.
} 
The dollar magnitudes of total seasonal supply shifters—seasonal variation in labor costs, for example-necessary to generate the seasonality we observe in interest costs can then be calculated by looking at the difference in average fees plus interest rates in each calendar month and the cheapest month to issue (May). This difference is multiplied by monthly dollar volume and summed up over the year. When we calculate the average annual seasonal cost from 20002011 (excluding the crisis years in 2008 and 2009), we find the dollar cost of seasonality is large: roughly $\$ 7$ billion per year. ${ }^{21} \$ 7$ billion is an especially large number when benchmarked against estimates of the total compensation of commercial bankers active in this market. As an example, consider that JP Morgan—easily the dominant lender in this market-arranged $30 \%$ of all transactions in 2011. If we conservatively assume JPMorgan bankers are paid comparably to lenders at other banks, then their share of the \$7BN seasonal labor costs would be $\$ 2.1 \mathrm{BN}$. Yet conversations with employees there suggest roughly 175 bankers work on JPMorgan's syndicated loan desk. Thus, for seasonal labor costs to drive rate seasonality, each worker would need to be paid a $\$ 12$ million dollar seasonal bonus ( $\$ 2.1$ billion divided by 175 ), in addition to their standard compensation. Even dividing that number by 3 to account for selection effects evident in the seasonality vastly overstates the total compensation of a typical loan officer. So while it is difficult to completely rule out that the cost of bank labor has a seasonal component, the magnitude of variation in spreads makes this an unlikely stand-alone explanation for our findings.

Another supply driven explanation for variation in rates and quantities could be that loan officers face non-linear incentives around evaluation dates for performance bonuses. See, for

\footnotetext{
${ }^{21}$ Including 2008 and 2009 drives the number down to \$5BN, primarily because the limited volume in the market during the credit tightening.
} 
example, work by Oyer (1998) on seasonal sales targets and Community Reinvestment Act lending around regulatory exams by Agarwal, Benmelech, Bergman, and Seru (2012). Just in advance of bonuses being set, one might imagine individual loan officers have incentives to ramp up loan volume, pushing down rates in those periods. We think this is an unlikely explanation for the seasonality for two reasons. First, anecdotally, bankers in the syndicated loan market are increasingly compensated based on their return on economic capital, and explicitly not on volume. Under this compensation model, the incentives to lend excessively at the yearend are diminished. Second, the timing doesn’t appear to match. Bonuses are typically awarded based on calendar year performance, which is hard to reconcile with the cheapest loans closing in May, June, and October.

Instead, we focus our analysis of lender behavior around models of imperfect competition. In particular, consider a setting in which a monopolist lender faces demand from firms with different preferences, unobservable to the lender. While some firms may be willing to pay a great deal for immediate financing, others will be more patient. In a perfectly competitive equilibrium, these preferences are irrelevant to the price charged, as competitive lenders will offer loans at their cost. For the monopolist bank, however, it may be profitable to price discriminate, charging each borrower as closely as possible to their willingness-to-pay, and thereby maximizing their share of the surplus associated with the transaction.

A number of pricing strategies have been shown to be effective in inducing borrowers to reveal and pay their true willingness-to-pay (WTP), either completely or at least partially (Dana and Anderson (2009)). Salop and Stiglitz (1977), for example, proposed a model of spatial variation in prices, in which low WTP purchasers search until they find a bargain, but high WTP purchasers forgo search costs and buy at the first store they find. In at least some of the cases, 
the seller will then be able to capture the high WTP buyers at their reservation price. Varian (1980) extends the model to allow for intertemporal price discrimination in which prices vary randomly in time. Low WTP purchasers wait for sales, while high WTP purchasers buy immediately. Finally, Stokey $(1979,1981)$ describes settings in which a seller facing a group of buyers who arrive at a single point in time but have the option to delay purchase. In special cases, sellers might profitably price discriminate by continually dropping prices, initially selling only to impatient high valuation customers, before lowering prices until the market clears and the lowest valuation purchaser has bought the good.

Our setting most closely resembles Conlisk, Gerstner, and Sobel (1984), which builds on Stokey (1981) by allowing new prospective purchasers (borrowers) to arrive continuously over time, generating a general prediction of cyclical price variation. As in Stokey, customers can time their purchases based on the anticipated price path set by the seller. The good is assumed to be durable, with high willingness-to-pay customers deriving more flow utility per period. Although the rate of time preference is the same across customers, high valuation customers are implicitly less patient, as the cost of delaying consumption reduces utility flow by more than for those with lower valuations.

Conlisk, Gerstner, and Sobel show that, under these assumptions, it is profitable for a seller (or in our case the bank) to vary prices (interest rates) cyclically, consistent with the patterns we show. Starting at some initial time period, prices can be set high enough to capture rents from high WTP customers, who rationally anticipate the forthcoming sale, but for whom the cost of waiting is too high. Meanwhile, low WTP customers, who find current prices unattractive, defer their purchases until the seller finally clears accumulated demand during what look like regular predictable sales. Once the market is cleared, the seller faces a problem that is 
isomorphic to its original problem. The seller thus repeats the same strategy, driving a cyclical price pattern similar to the one we observe.

The key prediction of the model of interest to us - the joint seasonal variation in interest rates and borrower type-is driven by a handful of key assumptions. With some large caveats, we argue these also map reasonably well to our setting and are consistent with the earlier results. First, the model assumes the continuous arrival of new customers, all of whom are "durable" in that they can defer their purchases until later periods; our borrowers identify new projects or changes to their capital structure continuously over time, yet generally have the option to wait. This opportunity to time the market allows patient borrowers with lower reservation interest rates to effectively separate from borrowers with higher reservation interest rates. By way of analogy, patient borrowers are able to borrow more cheaply in the same way that video game purchasers who are willing to delay their purchase of newly released video games pay discounted prices (Nair 2007). The good that buyers purchase is also durable. We can think of loans as durable in the sense that they generate profit flows for borrowers over time, and/or firms can borrow today to finance not just current, but future projects as well, just as soda purchasers with ample cupboard space can stockpile during sales in Hendel and Nevo's (2013) empirical application of a similar model to the retail setting. Durability of the product also generates a natural way to think about the deferability of different projects. Projects with higher value on a per period basis, and thus higher total present value, will be the most costly to defer, making implicit the link between a borrowers' reservation interest rates and their ability to wait. In practice, the high value projects behind high willingness-to-pay borrowers' funding needs may be more costly to defer because the borrower forgoes profits while waiting, because better projects are likely to be scooped by rivals, or because projects lose value if deferred. We provide the details of several 
examples of such projects in Appendix C. One such example is the German electric utility RWE's 9 billion Euro loan used to acquire Essent Network in January 2009. The acquisition opportunity was both of strategic importance to RWE and couldn't be deferred due to concerns that other bidders would enter if market conditions improved. Just as high costs of storage or the inability to perfectly anticipate funding prevent firms from borrowing ahead of markups, the imperfect ability to delay borrowings serves a similar role in preventing perfect intertemporal substitution.

The model also assumes sufficient consumer heterogeneity in terms of the valuation of the product (the funds being borrowed). In our setting this only requires that while some borrowers are only willing to borrower at bargain basement interest rates (e.g. precautionary borrowers who may or may not have eventual need liquidity), for other borrowers, immediate access to credit is critical and reflected by a willingness to pay a high interest rate. Perhaps most importantly, customers are assumed to be rational and therefore anticipate the cycles. The fact that CFO’s successfully match predictable needs like refinancing and CP back-up facilities with predictably cheap seasons, as shown in Table 5, supports this assumption. ${ }^{22}$

Where our setting may or may not match the key assumptions of the model is with respect to the competitive framework. Specifically, models of price discrimination rely critically on the assumption of a less than perfectly competitive industry structure. Under perfect competition, spreads collapse to marginal cost and rents from price discrimination are lost. In practice, the syndicated loan market is better characterized as an oligopoly of roughly a dozen

\footnotetext{
${ }^{22}$ Conlisk, Gerstner, and Sobel also assume there can be no resale market-in our context, borrowers cannot borrow cheaply and then assign their rights and obligations under the loan contract to another borrower at a more expensive rate during the expensive season. In theory, borrowers could borrow cheaply during sales, and then act as banks in the expensive season, lending at a positive spread. We think that this doesn't occur in practice for a variety of reasons. But if it did, we would think of this as a more direct violation of the assumption to be made in the next paragraph: no competition.
} 
banks that set terms for the vast majority of transactions, and a competitive fringe of outsider banks arranging a substantially smaller proportion of the market. Whereas a model of strategic price discrimination can easily explain why a monopolist lender might choose cyclical pricing, achieving $3^{\text {rd }}$-degree price discrimination under a more competitive industry structure depends on the ability of dominant banks to behave cooperatively to achieve the jointly optimal pricing schedule. Thus, the plausibility of price discrimination as an explanation for the seasonal patterns we observe will depend on the extent to which facilitating conditions for cooperative pricing exist, and, more importantly, the extent to which variation in those facilitating conditions affects the degree of seasonality we observe.

The syndicated loan market has several features that might support the ability to maintain seasonal pricing. First, whereas many investors participate in the market, only a handful of banks set interest rates as lead arrangers on most transactions. Intuitively, coordination costs are mitigated as the number of firms able to set prices falls. Second, the rates that banks set are, for the most part, publicly reported in firm's disclosures or by reporters in trade magazines or information clearing houses (e.g. DealScan). Thus, any deviations from the jointly optimal pricing schedule are observable to other banks, just as they are observable to the authors. Finally, the syndication business model demands repeated interactions among participants so that banks that have private incentives to "shirk"-underprice transactions during high rate seasons, for example - may fear retaliation from other lead arrangers. The combination of a concentrated market, visible conduct, and an ability to punish banks that undercut the optimal pricing schedule define classic facilitating conditions for the survival of cooperative pricing strategies.

We do observe variation in these facilitating conditions—-both market concentration and the ability to punish - in the time series and the cross-section. Our tests of the price 
discrimination hypothesis exploit that variation, beginning with variation in market concentration. In the time series, the share of loans led by the top 10 banks has moved substantially over time, falling as low as $59.2 \%$ and as high as $80.5 \%$. The dashed line in Figure 4 plots the percentage of loan market volume led by a lead arranger who was among the top ten lead arrangers from the prior year. (Lenders are ranked in terms of the dollar volume of transactions arranged.) A few noteworthy periods of consolidation are apparent. From 19911993, the top two lead arrangers, Chemical Bank and Citibank, nearly doubled their market share, partly related to Chemical's acquisition of Manufacturers Hanovers Trust. Similarly, from 1998-2001, Bank of America's merger with NationsBank and the merger of JPMorgan and Chase consolidated the volume of deals arranged by the top banks considerably. The reverse trend from 2002-2009, meanwhile, is less obvious, but appears to be driven by increased transaction flows to smaller non-US, in particular European, banks.

To the extent that market concentration facilitates cooperative behavior among lenders, a first test of the lenders' role in seasonality is to link the degree of seasonality to market concentration over time. Our primary hypothesis is that as the market becomes more dispersed, the ability to coordinate the optimal pricing schedule among an ever-growing contingent of banks will weaken, opportunistic lenders will move capital to high priced seasons, and the seasonal effects will attenuate. An alternative way of framing the hypothesis is that seasonality will soften as markets become more dispersed; the banks that benefit most from sustained seasonality—-those managing the most market volume-become less critical to satisfying borrower demand as the competitive fringe grows. Both interpretations are predicated on concentrated markets dominated by large banks facilitating the seasonal pricing. 
Returning to Figure 4, the solid line reports the magnitude of seasonality on an annual basis, estimated by regressing individual loan spreads on the seasonal effect variable (described in Table 2), year dummies, and the interaction of each year's dummy with the seasonal effect. The seasonal magnitude, captured by the coefficient on the year dummy times the seasonal effect variable, appears to follow lead arranger market concentration, as predicted. Table 6 formalizes this test, first presenting the actual seasonal interactions by year, along with standard errors and significance levels. We see that the seasonality's strength varies substantially by year. Meanwhile, panel B links that annual variation to the percentage of loan volume arranged by the top 10 banks in the prior year. Column 1 includes only time dummies as controls, while column 2 includes controls used in Table 2 to partial-out firm creditworthiness. The interaction between market concentration and seasonal effect captures the covariance between the strength of the "pure” seasonal effect (after conditioning out borrower risk) and market concentration. We present the results with market concentration demeaned and divided by its standard deviation, such that the economic interpretation of the interaction term refers to the variation in the strength of the seasonal effect related to a one standard deviation move in market concentration. With or without controls, seasonality appears to depend on the prevailing market structure; a one standard deviation increase in concentration nearly doubles the range of spreads from peak to trough. It shouldn't be surprising that the effect becomes smaller and less significant after controlling for firm and deal characteristics, as the sorting effects described in Section III should be expected to strengthen and weaken together with the "pure" seasonal effect. Meanwhile, in column 3 we add separate interactions for the level and volatility of spreads. The variable mean spreads reflects the average loan spread during each calendar year, while std. deviation monthly spreads is calculated based on the annual standard deviation of the 12 monthly average spreads 
during that year. Neither interaction drives out the seasonal variation, allowing us to reject this notion that seasonality is simply proxying for either market volatility or time variation in risk premiums which might plausibly be linked to lender consolidation or entry. ${ }^{23}$

A second way to examine the effect of concentration on seasonality is to exploit the cross-sectional variation in lender concentration across industries. Banks that specialize in oil and gas may be less active in telecom, and vice-versa, allowing for industry-by-industry variation in market structure and concentration. While we won't claim that lender concentration is random or unrelated to other market characteristics, it is a necessary facilitating condition for seasonality to sustain itself under the price discrimination mechanism described. Thus, it provides a sensible test of the theory. Whereas the time series tests focused on the yearly sensitivity to an established pattern of seasonality—something we might think of as the average seasonality across markets-there is nothing guaranteeing that different segments of the loan market will coordinate on the same seasonal pattern. Moreover, even if they did, variation in the time between loan negotiation and closing might drive some industries to look as though they had limited seasonality because the peaks and troughs occur in different months. As a result, we characterize highly seasonal industries as those with a high seasonal $\mathrm{R}^{2}$. For each industry, we

\footnotetext{
${ }^{23}$ Since bank loans are not the only source of debt capital for the firms in our sample, it is not enough that banks successfully coordinate among themselves. Bond investors, which can be thought of as an uncoordinated mass of lenders, would have similar effects on seasonality as an influx of new bank entrants. In Panel C, we replace bank market concentration with a measure of flows into corporate bond mutual funds. Flows are estimated using CRSP data as the change in total net assets for corporate bond funds, less year-end returns on the prior year's total net assets and are standardized to have mean zero and unit standard deviation. Corporate bond funds are flagged as those funds with CRSP mutual find style codes ICQH (high quality corporate bonds), ICQM (medium quality corporate bonds), and ICQY (high yield corporate bonds). Our time series starts in 1993, the first year Strategic Insight Objective codes used to construct CRSP fund objective codes are reported.

Focusing on the interaction between seasonal sensitivity and bond fund flows, we see that in periods of strong inflows (more competition) seasonality is attenuated (see Table 6 - Panel C). The coefficient on the interaction term between seasonality and fund flows of 1.09 in column 1. This means that a 1.6 standard deviation increase in fund flows is needed to completely remove the aggregate seasonal effect from our pricing regressions. These levels of flows occur only twice during our sample period. So while competition from the bond market affects seasonality in a manner similar to competition within the bank market, only in periods of extreme bond market liquidity is seasonality eliminated.
} 
create a time series of average monthly spreads, limiting ourselves to industries with at least 120 months of data. We then regress the time series of spreads for each industry on 12 calendar month dummies with no other controls and report the industry specific $\mathrm{R}^{2}$. This approach follows Miron (1996), who reports seasonal variation on a variety of economic indicators using the $\mathrm{R}^{2}$ from similar time series regressions and interprets them as the percentage of total time series variation attributable to seasonality. Unlike Miron, we use adjusted $\mathrm{R}^{2}$ to account for the degrees of freedom associated with the 12 monthly dummies as explanatory variables. Consistent with the rest of the paper, we identify industries using Fama and French's classification, and divide the loan market into 49 industry segments (47 are left after dropping industries with too few observations, see Figure 5a). To highlight an example, the industry with the highest seasonal adjusted $\mathrm{R}^{2}$ is candy and soda, with an adjusted R-squared of 7\%. At the other extreme, utilities have the lowest adjusted seasonal $R^{2}$ at $-4 \%$ (note, the negative adjusted $R^{2}$ indicates that after adjusting for the 12 monthly dummies, there is unlikely to be any real seasonality in utilities). Figure $5 \mathrm{~b}$ plots the mean monthly spreads for the two industries to show the actual seasonal effects, or lack thereof, directly. We will argue that it is not random that candy and soda also happens to be the industry with the second highest level of bank concentration, while utilities is among the most competitively banked sectors.

To measure market concentration, for each year and industry we calculate the percent of the loan market volume led by the top ten banks serving that industry. We then take an average of that percentage, for each industry, over the entire sample. Figure 5a plots each industry's seasonal adjusted $\mathrm{R}^{2}$ against the proposed measure of market concentration. As in the time series, we find industries with more concentrated banking markets tend to exhibit more seasonality in interest rate spreads. The correlation between the two measures is $54 \%$ (p-value $<1 \%$ ). Table 7 
extends the analysis by adding controls for industry size (average logged total annual dollar volume of issuance), the average level of loan spreads, and volatility of mean annual loan spreads over the sample period. While ex-ante we're agnostic about the predicted signs from these controls, we might worry that seasonality simply captures other statistical or economic properties in these markets. With these controls, a $10 \%$ level increase in market share of the top 10 banks increases seasonal adjusted $\mathrm{R}^{2}$ coefficients by 1 percentage point, or roughly half of one standard deviation.

Table 8 considers the second facilitating condition for a cooperative pricing strategy, which is the ability to punish rogue lenders who undermine the optimal pattern of sales and pricing. In our view, we can imagine a number of possible mechanisms for punishment. For example, future transactions of shirking banks may not be subscribed to by their peers. Yet in equilibrium, we don't expect to see punishment occur. Punishment sufficient to uphold the equilibrium must deter shirking and thus won't be observable to the econometrician.

If, however, punishment depends on repeated interactions, then the limited frequency of interaction with other banks may make the threat of punishment weaker for "outsider" banks. Without frequent interactions with other banks in the loan market, banks that are less active will be harder to effectively discipline and therefore have more incentive to undermine the equilibrium. We should see these banks increase market share during high priced periods without the threat of subsequent punishment.

We test this prediction by looking at the seasonal variation in the probability of a bank from outside the top-ten (ranked by lead arranger volume from the prior year) leading a transaction for an investment grade rated borrower. We focus on the subsample of investment grade borrowers because these transactions are unconditionally less likely to be led by the 
smaller banks, absent the advantage they are ceded by the larger banks committed to maintain elevated pricing during the summer and winter periods. Columns 1 through 3 report the marginal impact of the seasonal pricing effect (reported as a percentage) on the probability of a non-top 10 bank serving as the lead arranger (or lead arrangers in the case of jointly lead deals) for investment grade borrowers. The key control in column 2 is the inclusion of borrower size, which, even within investment grade borrowers, may be correlated with the probability of an outsider bank leading the transaction. We also include other firm controls including ratings, as well as deal characteristics. Finally, in column 3 we add firm fixed effects and replace the probit specification with a linear probability model to isolate the impact of issuance season on lender choice for a given borrower. In each case, the effect is statistically and economically significant. The smallest estimates imply that the peak to trough variation in seasonal spreads of 20bps (0.2\%) drives a 3.7\% increase in the likelihood a given borrower will tap an outsider bank to lead its transaction. This is a large effect, especially considering the unconditional probability of an outsider bank leading an investment grade deal of just $16 \%$.

Figure 6, meanwhile presents the corresponding visual evidence, with side-by-side plots of the seasonal effect for investment grade rated borrowers and the percentage of transactions led by banks outside the top 10. From the seasonal trough prices in June to the peak in February, the probability of a smaller, outsider bank successfully winning a mandate from a top borrower increases from $12.9 \%$ to $17.3 \%$.

The entry of fringe banks during expensive periods provides the counterintuitive result, albeit consistent with the model of price discrimination presented above, that markets appear more competitive during periods of high prices. In this case, the high prices attract competition via the entry of smaller players. Due to their limited size and risk capacity, they are unable to 
entirely compete seasonal rents away. Meanwhile, the evidence of entry is indicative both of the economic magnitude of the underlying effect, and also would seem to undermine alternative riskbased explanations. If the risk-adjusted return earned on loans is the same across the year or if risk-adjusted seasonal markups are not economically significant, there should be no incentives for the competitive fringe to poach transactions during the more "expensive" months. Thus, we can view the evidence from Table 8 as suggestive of a coordinated pricing pattern among large banks and as reinforcing the economic significance of the seasonal effect.

\section{Discussion}

The patterns of recurring periods of markups and discounts in the market for corporate debt raise questions about both the dynamic nature of borrower demand for credit over relatively short horizons and the competitive behavior of large banks. The evidence presented suggests that firms with already low costs of funds are prone to time the market when sales occur, and then store liquidity in anticipation of future funding needs. High costs borrowers, meanwhile, appear less prone to precautionary borrowings during cheap periods and instead tend to fund themselves, sometimes during predictably high cost periods, as needs arise. Given the anticipation of loan sales in the future, the financings raised during high costs periods appear to be driven by unpredictable and non-deferrable capital needs. To the extent that the differences in the projects financed across seasons and the resulting borrower willingness to pay may otherwise be unobservable to the econometrician (as well as the bank), one modest suggestion is that the inclusion of seasonal controls may be appropriate in settings where financing costs are an outcome of interest. 
On the lender side, we have argued that this predictable fluctuation in costs of funds fits the patterns of intertemporal price discrimination described in the industrial organization literature. The evidence on cooperative rate setting by lenders is open to a range of interpretations. An extreme interpretation would imagine lenders are explicit in forming a cartel, deriving the optimal price schedule, and designing and implementing explicit modes of punishment for those who break rank. A more nuanced, and we believe a more plausible, interpretation requires neither a strong statement about the origins of seasonality, nor lender intent. It instead asks, given the presence of a pricing pattern which is ex-post optimal for the group, what are the incentives to compete it away. In this context, seasonality exists as a fortunate anomaly which less-than-perfectly-competitive lenders are more than happy to preserve.

This argument matches well with one suggested source of the seasonality centered around US winter and summer vacation schedules, both typically expensive seasons. While we argued that seasonal labor costs can’t plausibly explain the magnitude of the seasonal effect we observe, they might provide a focal point around which banks could naturally converge on softer competition. ${ }^{24}$ Consider for example that bankers have incentives to be out of the office during holidays, perhaps pricing bids on new deals less aggressively to preserve family vacations. Yet from a governance perspective, shareholders have limited incentives to correct this if it achieves, as we've argued, the effects of third degree price discrimination. Thus, allowing loan officers to

\footnotetext{
${ }^{24}$ In theory, seasonal price discrimination could focus on any calendar date. GE and Westinghouse famously used the phase of the moon to coordinate pricing of turbines used for electrical generation (see Lewis and McAfee (2009)).
} 
accrue rents in the form of more relaxed summers and winter holidays is optimal for bank shareholders, as long as other bank shareholders allow the same. ${ }^{25}$

Meanwhile, note that we've also made no statements regarding the welfare implications of this behavior. Third degree price discrimination may be strictly preferable in the aggregate to Cournot competition among a handful of lenders, to the extent that banks are less prone to under produce credit when they capture the entire surplus from a given transaction. Moreover, if lender rents mitigate excess risk taking, as has been suggested by some in the bank competition literature, then seasonality and the related rents may also generate positive externalities for the broader economy.

${ }^{25}$ Thanks to for Chris Parsons for helping guide us to this intuition. 
Table 1: Season Variation in Loan Spreads and Volumes. The table contains tests of seasonality across the calendar year for the average loan spreads and volumes from our sample as well as a set of market interest rates. Loan spreads (volumes) are averaged (summed up) for each month times year and thus the unit of observation is a month-year. Tests of seasonality of average loan spreads and logged dollar volumes of issuance are reported in Columns 1 and 2. Both regressions include monthly and yearly dummies. The F-statistics test the hypothesis that the monthly dummies are jointly zero (i.e. there is no seasonality in the data). The year dummies are replaced with autoregressive lags of the dependent variable in Columns 3 and 4 . The test from column 1 is repeated on 3-month LIBOR (Column 5), the spread between Baa and Aaa rated bonds (Column 6), and the average monthly quoted CDS spreads for dollar denominated contracts on non-Government names covered in the Markit CDS database (Column 7). With the exception of the data on CDS spreads, the sample period is January 1987December 2012. For sample for the CDS spreads is 2001-2010. Loan dates are based on effective date: the date on which loan documents become effective and typically the first date the borrower can draw down. Newey-West standard errors with a lag length of 12 months are reported in parentheses. Statistical significance at the 1, 5, or $10 \%$ levels is reported as superscripts. Constants are excluded from all models.

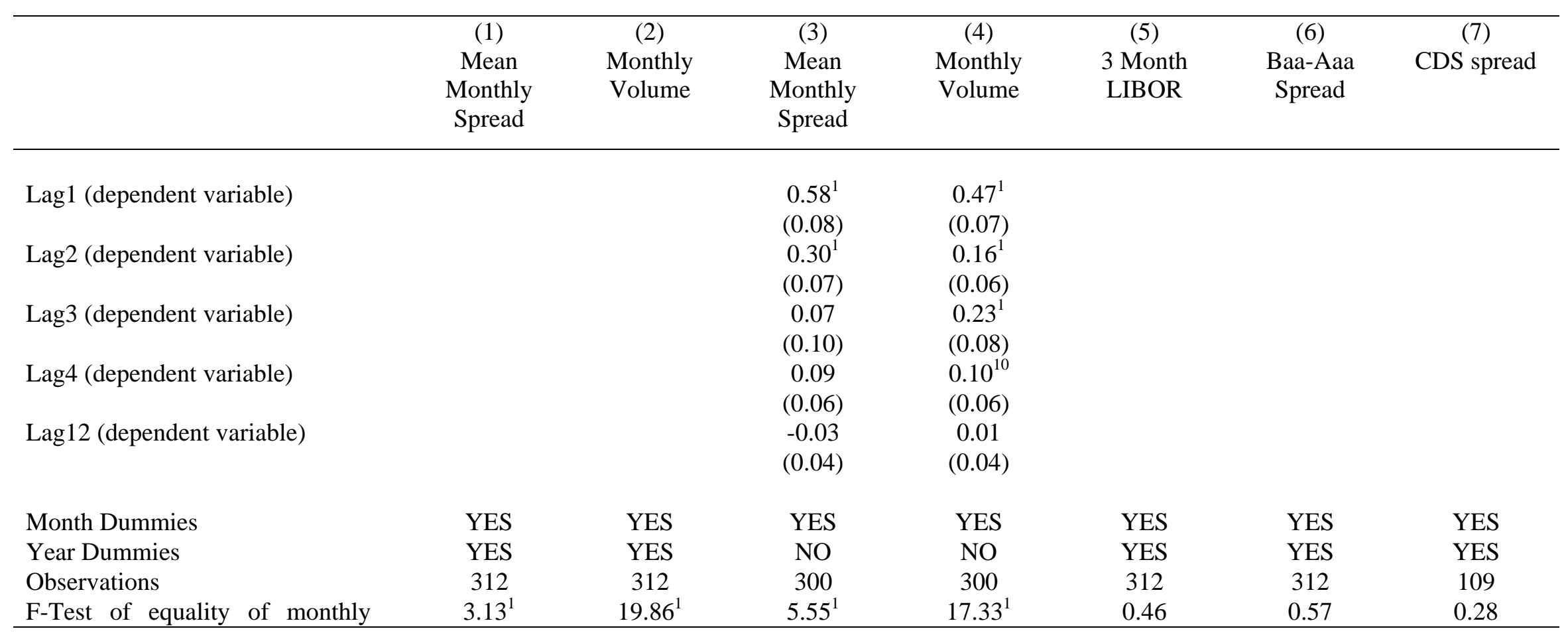


Table 2: Loan Level Seasonality. Table 2 estimates regressions of loan spread on seasonal variables and controls, including long term debt ratings and prevailing credit default swaps spreads for the borrower in the month of issuance and loan characteristics. Cheap Season and Expensive Season dummies denote the month in which the deal was closed. Expensive-Cheap at the bottom of the table reports the spread difference between issuance in January, February, and August (expensive) and issuance in May, June, and October (cheap). Seasonal effect is the monthly/seasonal prediction in loan spread from the holdout sample of non-Compustat firms. Standard errors on coefficients and tests of differences in seasonal spreads are clustered by firm and month and are reported in parentheses. Statistical significance at the 1, 5, or $10 \%$ levels is reported as superscripts.

\begin{tabular}{|c|c|c|c|c|c|c|}
\hline \multirow[b]{2}{*}{ Loan Spread (in basis points) } & \multicolumn{5}{|c|}{ Rated Sample } & \multirow[b]{2}{*}{ (6) } \\
\hline & $(1)$ & $(2)$ & $(3)$ & $(4)$ & $(5)$ & \\
\hline Seasonal Effect (holdout sample) & & & & & $\begin{array}{c}0.60^{1} \\
(0.21)\end{array}$ & $\begin{array}{l}0.51^{5} \\
(0.21)\end{array}$ \\
\hline Cheap Season (May, June, Oct) & $\begin{array}{l}-4.02 \\
310)\end{array}$ & $\begin{array}{l}-0.08 \\
237)\end{array}$ & -1.80 & -0.51 & & \\
\hline Expensive Season (Jan, Feb, Aug) & $\begin{array}{l}14.96^{1} \\
(4.20)\end{array}$ & $\begin{array}{l}10.91^{1} \\
(3.07)\end{array}$ & $\begin{array}{l}5.51^{5} \\
(2.37)\end{array}$ & $\begin{array}{c}5.31^{5} \\
(2.46)\end{array}$ & & \\
\hline $\ln$ (Maturity) & & $\begin{array}{l}-3.03 \\
(2.17)\end{array}$ & $\begin{array}{l}-4.24^{1} \\
(1.60)\end{array}$ & $\begin{array}{l}-2.86^{10} \\
(1.55)\end{array}$ & $\begin{array}{l}-4.23^{1} \\
(1.60)\end{array}$ & $\begin{array}{l}-2.86^{10} \\
(1.55)\end{array}$ \\
\hline Secured & & $\begin{array}{c}119.13^{1} \\
(3.32)\end{array}$ & $\begin{array}{l}30.98^{1} \\
(3.47)\end{array}$ & $\begin{array}{l}24.04^{1} \\
(3.46)\end{array}$ & $\begin{array}{l}30.87^{1} \\
(3.47)\end{array}$ & $\begin{array}{l}23.93^{1} \\
(3.45)\end{array}$ \\
\hline $\ln$ (Assets) & & & $\begin{array}{l}-1.48 \\
(1.17)\end{array}$ & $\begin{array}{c}0.93 \\
(2.86)\end{array}$ & $\begin{array}{l}-1.53 \\
(1.17)\end{array}$ & $\begin{array}{c}1.02 \\
(2.85)\end{array}$ \\
\hline Operating Profit/Assets & & & $\begin{array}{c}-152.89^{1} \\
(16.78)\end{array}$ & $\begin{array}{c}-195.77^{1} \\
(23.72)\end{array}$ & $\begin{array}{c}-152.73^{1} \\
(16.77)\end{array}$ & $\begin{array}{c}-195.88^{1} \\
(23.69)\end{array}$ \\
\hline Total Debt/Assets & & & $\begin{array}{l}37.54^{1} \\
(5.31)\end{array}$ & $\begin{array}{l}35.71^{1} \\
(9.86)\end{array}$ & $\begin{array}{l}37.39^{1} \\
(5.31)\end{array}$ & $\begin{array}{l}35.46^{1} \\
(9.84)\end{array}$ \\
\hline PP\&E/Assets & & & $\begin{array}{c}1.75 \\
(5.73)\end{array}$ & $\begin{array}{c}15.55 \\
(14.14)\end{array}$ & $\begin{array}{c}1.50 \\
(5.73)\end{array}$ & $\begin{array}{c}15.71 \\
(14.14)\end{array}$ \\
\hline Time Fixed Effects & YES & YES & YES & YES & YES & YES \\
\hline Deal Purpose Fixed Effects & NO & YES & YES & YES & YES & YES \\
\hline Industry Fixed Effects & NO & NO & YES & - & YES & - \\
\hline Ratings Fixed Effects & NO & NO & YES & YES & YES & YES \\
\hline Firm Fixed Effects & NO & NO & NO & YES & NO & YES \\
\hline Observations & 12,087 & 12,087 & 12,087 & 11,414 & 12,087 & 11,414 \\
\hline $\mathrm{R}^{2}$ & 0.12 & 0.41 & 0.63 & 0.77 & 0.63 & 0.77 \\
\hline Expensive-Cheap & $\begin{array}{l}18.98^{1} \\
(4.66)\end{array}$ & $\begin{array}{l}10.99^{1} \\
(3.28)\end{array}$ & $\begin{array}{c}7.31^{1} \\
(2.38)\end{array}$ & $\begin{array}{c}5.82^{5} \\
(2.53)\end{array}$ & & \\
\hline
\end{tabular}


Table 2: Loan Level Seasonality (continued).

\begin{tabular}{|c|c|c|}
\hline \multirow[b]{2}{*}{ Loan Spread (in basis points) } & \multicolumn{2}{|c|}{ CDS Sample } \\
\hline & $(7)$ & $(8)$ \\
\hline Seasonal Effect (holdout sample) & & $\begin{array}{c}0.73^{5} \\
(0.29)\end{array}$ \\
\hline Cheap Season (May, June, Oct) & $\begin{array}{l}-2.42 \\
(2.78)\end{array}$ & \\
\hline Expensive Season (Jan, Feb, Aug) & $\begin{array}{c}4.97 \\
(3.62)\end{array}$ & \\
\hline $\ln$ (Maturity) & $\begin{array}{c}0.82 \\
(2.02)\end{array}$ & $\begin{array}{c}1.34 \\
(1.93)\end{array}$ \\
\hline Secured & $\begin{array}{l}23.53^{1} \\
(5.70)\end{array}$ & $\begin{array}{l}23.24^{1} \\
(5.73)\end{array}$ \\
\hline CDS Spread & $\begin{array}{c}0.30^{1} \\
(0.03)\end{array}$ & $\begin{array}{l}0.29^{1} \\
(0.03)\end{array}$ \\
\hline$($ CDS Spread/100)2 & $\begin{array}{l}-1.04^{1} \\
(0.15)\end{array}$ & $\begin{array}{l}-1.02^{1} \\
(0.15)\end{array}$ \\
\hline $\ln$ (Assets) & $\begin{array}{l}-2.00 \\
(1.80)\end{array}$ & $\begin{array}{c}-2.09 \\
(1.79)\end{array}$ \\
\hline Operating Profit/Assets & $\begin{array}{l}-48.34 \\
(30.76)\end{array}$ & $\begin{array}{c}-53.39^{10} \\
(30.99)\end{array}$ \\
\hline Total Debt/Assets & $\begin{array}{c}17.12 \\
(11.58)\end{array}$ & $\begin{array}{l}19.66^{10} \\
(11.64)\end{array}$ \\
\hline PP\&E/Assets & $\begin{array}{l}-21.97^{5} \\
(9.01)\end{array}$ & $\begin{array}{c}-19.13^{5} \\
(8.90)\end{array}$ \\
\hline Time Fixed Effects & YES & YES \\
\hline Deal Purpose Fixed Effects & YES & YES \\
\hline Industry Fixed Effects & YES & YES \\
\hline Ratings Fixed Effects & YES & YES \\
\hline Observations & 2,064 & 2,064 \\
\hline $\mathrm{R}^{2}$ & 0.78 & 0.78 \\
\hline Expensive-Cheap & $\begin{array}{c}7.39^{5} \\
(3.67)\end{array}$ & \\
\hline
\end{tabular}


Table 3: Loan Issuance Timing: The Seasonal Effect. Table 3 estimates an ordered probit model of the decision to issue during the cheap season (-1) vs. the rest of year (0) vs. the expensive season (1). Below the model estimates, we report the marginal effect of the log CDS spread (or the change in the log CDS spread) on the probability of issuing during each season. Independent variables are standardized (zero mean and unit variance) such that the marginal effect can be interpreted as the effect of a one standard deviation change in the variable of interest on the probability of issuance in a given season. Standard errors clustered by firm and month are reported in parentheses. Statistical significance at the 1, 5, or $10 \%$ levels is reported as superscripts.

\begin{tabular}{|c|c|c|c|c|}
\hline Issuance Season (order from cheap to expensive) & $(1)$ & $(2)$ & $(3)$ & (4) \\
\hline $\ln ($ CDS Spread) & $\begin{array}{c}0.08^{5} \\
(0.03)\end{array}$ & & $\begin{array}{l}0.07^{10} \\
(0.04)\end{array}$ & $\begin{array}{c}0.08^{5} \\
(0.04)\end{array}$ \\
\hline$\Delta \ln (\mathrm{CDS}$ Spread)t,t-6 & & $\begin{array}{c}0.05 \\
(0.05)\end{array}$ & $\begin{array}{c}0.03 \\
(0.05)\end{array}$ & \\
\hline$\Delta \ln ($ CDS Spread)t+6,t-6 & & & & $\begin{array}{c}0.01 \\
(0.08)\end{array}$ \\
\hline$\partial \operatorname{Pr}($ Cheap Season $)$ & $-0.026^{5}$ & -0.016 & & \\
\hline$\overline{\partial x}$ & $(.011)$ & (0.019) & & \\
\hline$\partial \operatorname{Pr}($ Rest of Year $)$ & 0.006 & 0.004 & & \\
\hline$\partial x$ & $(0.004)$ & $(0.004)$ & & \\
\hline$\partial \operatorname{Pr}($ Expensive Season $)$ & $0.020^{5}$ & 0.012 & & \\
\hline$\partial x$ & $(0.009)$ & $(.014)$ & & \\
\hline Time Fixed Effects & YES & YES & YES & YES \\
\hline Industry Fixed Effects & YES & YES & YES & YES \\
\hline Observations & 2,064 & 1,772 & 1,772 & 1,687 \\
\hline
\end{tabular}


Table 4: Uses of funding in the quarter of issuance. Table 4 compares changes in various sources and uses of cash around the time of loan issuance for cheap and expensive season issuers. Cheap season issuers are borrowers whose loans close in May, June, or October, and expensive season borrowers had loans close in January, February, and August. In each case, changes in cash flow are scaled by the total volume of issuance from the DealScan sample by that borrower over the quarter. Repeat borrowers within a fiscal quarter whose borrowings happened over different seasons were excluded from the sample. Columns 5-8 test the differential effect for high and low rate borrowers, which are defined as the firms with average interest rate spreads which place them above (below) the $75^{\text {th }}$ percentile of observations respectively. Standard errors are clustered by firm and quarter and are reported in parentheses. Statistical significance at the 1, 5, or $10 \%$ levels is reported as superscripts.

\begin{tabular}{|c|c|c|c|c|c|c|c|c|}
\hline \multirow[b]{2}{*}{ Cheap Season (May, Jun, Oct) } & \multicolumn{2}{|c|}{$\begin{array}{l}(1) \\
\text { Financing cash flow/ } \\
\text { Issuance Size }\end{array}$} & \multicolumn{2}{|c|}{$\begin{array}{l}\text { (3) (4) } \\
\text { Investment / } \\
\text { Issuance Size }\end{array}$} & \multicolumn{2}{|c|}{$\begin{array}{l}\text { (5) } \\
\text { Financing cash flow/ } \\
\text { Issuance Size }\end{array}$} & \multicolumn{2}{|c|}{$\begin{array}{l}(7) \quad(8) \\
\text { Investment / } \\
\text { Issuance Size } \\
\end{array}$} \\
\hline & $\begin{array}{c}0.001 \\
(0.008)\end{array}$ & $\begin{array}{c}0.000 \\
(0.010)\end{array}$ & $\begin{array}{l}-0.006 \\
(0.008)\end{array}$ & $\begin{array}{l}-0.010 \\
(0.009)\end{array}$ & $\begin{array}{c}0.019 \\
(0.016)\end{array}$ & $\begin{array}{c}0.015 \\
(0.021)\end{array}$ & $\begin{array}{l}-0.002 \\
(0.015)\end{array}$ & $\begin{array}{l}-0.001 \\
(0.019)\end{array}$ \\
\hline Expensive Season (Jan, Feb, Aug) & $\begin{array}{l}0.025^{1} \\
(0.009)\end{array}$ & $\begin{array}{l}0.025^{5} \\
(0.010)\end{array}$ & $\begin{array}{l}0.014^{10} \\
(0.009)\end{array}$ & $\begin{array}{l}0.022^{1} \\
(0.008)\end{array}$ & $\begin{array}{c}0.003 \\
(0.019)\end{array}$ & $\begin{array}{c}0.000 \\
(0.020)\end{array}$ & $\begin{array}{l}-0.019 \\
(0.017)\end{array}$ & $\begin{array}{l}-0.000 \\
(0.018)\end{array}$ \\
\hline Cheap Season X Low Rate Borrower & & & & & $\begin{array}{l}-0.024 \\
(0.017)\end{array}$ & $\begin{array}{l}-0.020 \\
(0.022)\end{array}$ & $\begin{array}{l}-0.005 \\
(0.017)\end{array}$ & $\begin{array}{l}-0.012 \\
(0.019)\end{array}$ \\
\hline Expensive Season X Low Rate Borrower & & & & & $\begin{array}{c}0.030 \\
(0.019)\end{array}$ & $\begin{array}{c}0.031 \\
(0.022)\end{array}$ & $\begin{array}{l}0.044^{5} \\
(0.018)\end{array}$ & $\begin{array}{c}0.029 \\
(0.020)\end{array}$ \\
\hline Low Rate Borrower & $\begin{array}{l}-0.036^{1} \\
(0.009)\end{array}$ & & $\begin{array}{l}-0.013 \\
(0.009)\end{array}$ & & $\begin{array}{l}-0.036^{1} \\
(0.011)\end{array}$ & & $\begin{array}{c}-0.021^{10} \\
(0.012)\end{array}$ & \\
\hline Cash Flow from Operations & $\begin{array}{l}-0.390^{1} \\
(0.017)\end{array}$ & $\begin{array}{l}-0.410^{1} \\
(0.019)\end{array}$ & $\begin{array}{c}0.371^{1} \\
(0.015)\end{array}$ & $\begin{array}{c}0.317^{1} \\
(0.018)\end{array}$ & $\begin{array}{l}-0.390^{1} \\
(0.017)\end{array}$ & $\begin{array}{l}-0.410^{1} \\
(0.020)\end{array}$ & $\begin{array}{l}0.371^{1} \\
(0.015)\end{array}$ & $\begin{array}{c}0.317^{1} \\
(0.018)\end{array}$ \\
\hline Fiscal Quarter Dummies & YES & YES & YES & YES & YES & YES & YES & YES \\
\hline Year Fixed Effects & YES & YES & YES & YES & YES & YES & YES & YES \\
\hline Observations & 20,717 & 18,703 & 20,717 & 18,703 & 20,717 & 18,703 & 20,717 & 18,703 \\
\hline $\mathrm{R}^{2}$ & 0.116 & 0.418 & 0.119 & 0.440 & 0.116 & 0.418 & 0.119 & 0.441 \\
\hline $\begin{array}{l}\text { Expensive-Cheap } \\
\text { (Expensive-Cheap) x Low Rate Borrower }\end{array}$ & $0.024^{5}$ & $0.025^{5}$ & $0.020^{5}$ & $0.032^{1}$ & $\begin{array}{l}-0.016 \\
0.054^{5}\end{array}$ & $\begin{array}{l}-0.015 \\
0.051^{10}\end{array}$ & $\begin{array}{l}-0.017 \\
0.049^{5}\end{array}$ & $\begin{array}{c}0.001 \\
0.041^{10}\end{array}$ \\
\hline
\end{tabular}


Table 5: Deal Type. Table 5 reports the two way tabulation of deal purpose (top panel) and loan type (bottom panel) by issuance season, along with test of row/column independence. Issuance date is based on facility effective date. We aggregate deal purpose and loan type for transaction types with less than 1,000 observations in the merged DealScan-Compustat sample in the "other" category.

\begin{tabular}{|c|c|c|c|c|c|c|c|c|c|}
\hline & $\begin{array}{c}\text { CP } \\
\text { Backup }\end{array}$ & $\begin{array}{c}\text { Working } \\
\text { Capital }\end{array}$ & $\begin{array}{c}\text { Corp. } \\
\text { Purposes }\end{array}$ & $\begin{array}{c}\text { Debt } \\
\text { Repay. }\end{array}$ & $\begin{array}{l}\text { Acquis. } \\
\text { Line }\end{array}$ & LBO & $\begin{array}{l}\text { Take- } \\
\text { over }\end{array}$ & Other & Total \\
\hline Cheap Season (May, Jun, Oct) & $\begin{array}{c}938 \\
5.43 \%\end{array}$ & $\begin{array}{c}2,361 \\
13.67 \%\end{array}$ & $\begin{array}{c}6,838 \\
39.60 \%\end{array}$ & $\begin{array}{c}3,001 \\
17.38 \%\end{array}$ & $\begin{array}{c}716 \\
4.15 \%\end{array}$ & $\begin{array}{c}562 \\
3.25 \%\end{array}$ & $\begin{array}{c}1,462 \\
8.47 \%\end{array}$ & $\begin{array}{l}1,390 \\
8.05 \%\end{array}$ & $\begin{array}{c}17,268 \\
100\end{array}$ \\
\hline Expensive Season (Jan, Feb, Aug) & $\begin{array}{c}439 \\
3.56 \%\end{array}$ & $\begin{array}{c}1,776 \\
14.39 \%\end{array}$ & $\begin{array}{c}4,626 \\
37.48 \%\end{array}$ & $\begin{array}{c}2,046 \\
16.58 \%\end{array}$ & $\begin{array}{c}556 \\
4.50 \%\end{array}$ & $\begin{array}{c}516 \\
4.18 \%\end{array}$ & $\begin{array}{c}1,346 \\
10.91 \%\end{array}$ & $\begin{array}{c}1,037 \\
8.40 \%\end{array}$ & $\begin{array}{c}12,342 \\
100\end{array}$ \\
\hline TOTAL & $\begin{array}{l}2,723 \\
4.46 \% \\
\end{array}$ & $\begin{array}{c}8,703 \\
14.26 \% \\
\end{array}$ & $\begin{array}{r}23,399 \\
38.33 \% \\
\end{array}$ & $\begin{array}{l}10,753 \\
17.62 \% \\
\end{array}$ & $\begin{array}{l}2,688 \\
4.40 \% \\
\end{array}$ & $\begin{array}{l}2,139 \\
3.50 \% \\
\end{array}$ & $\begin{array}{r}5,604 \\
9.18 \% \\
\end{array}$ & $\begin{array}{r}5,030 \\
8.24 \% \\
\end{array}$ & $\begin{array}{c}61,039 \\
100 \\
\end{array}$ \\
\hline$\chi 2$ test of rows column independence & $61.3^{1}$ & $5.9^{5}$ & $10.6^{1}$ & $13.3^{5}$ & 3.6 & $20.7^{1}$ & $52.4^{1}$ & 1.2 & $169.0^{1}$ \\
\hline Cheap Season (May, Jun, Oct) & $\begin{array}{c}336 \\
1.95 \%\end{array}$ & $\begin{array}{c}611 \\
3.54 \%\end{array}$ & $\begin{array}{c}2,612 \\
15.13 \%\end{array}$ & $\begin{array}{c}7,848 \\
45.45 \%\end{array}$ & $\begin{array}{c}354 \\
2.05 \%\end{array}$ & $\begin{array}{c}352 \\
2.04 \%\end{array}$ & $\begin{array}{c}3,930 \\
22.76 \%\end{array}$ & $\begin{array}{l}1,225 \\
7.09 \%\end{array}$ & $\begin{array}{c}17,268 \\
100 \%\end{array}$ \\
\hline Expensive Season (Jan, Feb, Aug) & $\begin{array}{c}297 \\
2.41 \%\end{array}$ & $\begin{array}{c}482 \\
3.91 \%\end{array}$ & $\begin{array}{c}1,552 \\
12.57 \%\end{array}$ & $\begin{array}{c}5,367 \\
43.49 \%\end{array}$ & $\begin{array}{c}255 \\
2.07 \%\end{array}$ & $\begin{array}{c}243 \\
1.97 \%\end{array}$ & $\begin{array}{c}3,054 \\
24.74 \%\end{array}$ & $\begin{array}{c}1,092 \\
8.85 \%\end{array}$ & $\begin{array}{c}12,342 \\
100 \%\end{array}$ \\
\hline Rest of Year & $\begin{array}{c}582 \\
1.85 \%\end{array}$ & $\begin{array}{l}1,119 \\
3.56 \%\end{array}$ & $\begin{array}{c}4,493 \\
14.3 \%\end{array}$ & $\begin{array}{l}13,988 \\
44.51 \%\end{array}$ & $\begin{array}{c}661 \\
2.1 \%\end{array}$ & $\begin{array}{c}661 \\
2.1 \%\end{array}$ & $\begin{array}{c}7,588 \\
24.14 \%\end{array}$ & $\begin{array}{l}2,336 \\
7.43 \%\end{array}$ & $\begin{array}{c}31,428 \\
100 \%\end{array}$ \\
\hline$\gamma_{2}$ test of rows column independence & $\begin{array}{c}1,215 \\
1.99 \\
13.9^{1}\end{array}$ & $\begin{array}{c}2,212 \\
3.62 \\
3.4\end{array}$ & $\begin{array}{l}8,657 \\
14.18 \\
33.6^{1}\end{array}$ & $\begin{array}{c}27,203 \\
44.57 \\
6.3^{1}\end{array}$ & $\begin{array}{c}1,270 \\
2.08 \\
0.2\end{array}$ & $\begin{array}{c}1,256 \\
2.06 \\
0.8\end{array}$ & $\begin{array}{c}14,572 \\
23.87 \\
13.9^{1}\end{array}$ & $\begin{array}{c}4,653 \\
7.62 \% \\
32.1^{1}\end{array}$ & $\begin{array}{c}61,038 \\
100 \% \\
\mathbf{1 0 4 . 2}^{1}\end{array}$ \\
\hline
\end{tabular}


Table 6: Seasonality by year. In Panel A, we estimate a regression of loan spreads on year fixed effects and the seasonal effect variable (predicted monthly spreads estimated from the holdout sample of non-Compustat firms) interacted with each year's dummy. Reported below are the interaction terms, representing the year-to-year sensitivity to seasonal pricing. Panel B reports the results from a regression of loan spreads on the seasonal effect interacted with the percent of loan volume originated by the top 10 lead banks in the prior year's lead arranger league tables (Loan Market Concentration). Column 3 adds interactions with the mean level of annual spreads and the yearly volatility of monthly mean spreads, both estimated from the holdout sample. Unreported controls include $\ln ($ Maturity), Secured, $\ln ($ Assets), Operating Profit/Assets, Total Debt/Assets, PP\&E/Assets, plus 17 Fama-French Industry dummies, deal purpose, and ratings dummies. Standard errors are clustered by firm and month and are reported in parentheses. Statistical significance at the 1, 5, or $10 \%$ levels is reported as superscripts.

\begin{tabular}{ccccccccccc}
\multicolumn{2}{c}{ Panel A: Seasonal Effect (holdout sample) X Year } \\
$\mathbf{1 9 9 0}$ & $\mathbf{1 9 9 1}$ & $\mathbf{1 9 9 2}$ & $\mathbf{1 9 9 3}$ & $\mathbf{1 9 9 4}$ & $\mathbf{1 9 9 5}$ & $\mathbf{1 9 9 6}$ & $\mathbf{1 9 9 7}$ & $\mathbf{1 9 9 8}$ & $\mathbf{1 9 9 9}$ & $\mathbf{2 0 0 0}$ \\
\hline-0.25 & 0.75 & 0.31 & $2.50^{10}$ & $2.32^{5}$ & -0.72 & -0.60 & $1.62^{1}$ & -0.28 & $1.67^{5}$ & $2.41^{1}$ \\
$(1.55)$ & $(1.87)$ & $(0.93)$ & $(1.31)$ & $(1.06)$ & $(0.51)$ & $(1.11)$ & $(0.52)$ & $(0.72)$ & $(0.75)$ & $(0.72)$ \\
& & & & & & & & & & \\
$\mathbf{2 0 0 1}$ & $\mathbf{2 0 0 2}$ & $\mathbf{2 0 0 3}$ & $\mathbf{2 0 0 4}$ & $\mathbf{2 0 0 5}$ & $\mathbf{2 0 0 6}$ & $\mathbf{2 0 0 7}$ & $\mathbf{2 0 0 8}$ & $\mathbf{2 0 0 9}$ & $\mathbf{2 0 1 0}$ & $\mathbf{2 0 1 1}$ \\
\hline $1.94^{1}$ & $2.76^{1}$ & $4.46^{1}$ & $4.44^{1}$ & 2.14 & 0.13 & 0.54 & -2.71 & -1.03 & $2.12^{1}$ & $4.61^{1}$ \\
$(0.58)$ & $(0.82)$ & $(0.55)$ & $(1.33)$ & $(1.52)$ & $(0.71)$ & $(0.80)$ & $(2.20)$ & $(1.12)$ & $(0.74)$ & $(1.22)$
\end{tabular}

Panel B: Seasonal Effect (holdout sample) X Bank Market Concentration

Loan Spread (in basis points)

(1) (2) (3)

Seasonal Effect (holdout sample)

$\begin{array}{lll}1.74^{1} & 0.63^{1} & 0.66\end{array}$

Seasonal Effect (holdout sample) X \% Loan Market Concentration

$(0.38) \quad(0.21) \quad(0.20)$

$\begin{array}{lll}0.94^{1} & 0.43^{5} & 0.73^{1}\end{array}$

Seasonal Effect (holdout sample) X \% Mean Spreads

$(0.36) \quad(0.21) \quad(0.26)$

Seasonal Effect (holdout sample) X \% Std. Dev Monthly Spreads

Time Dummies

Deal Purpose Dummies

Industry Dummies

Ratings Dummies

Other Controls

YES YES YES

Observations

\begin{tabular}{ccc} 
NO & YES & YES \\
NO & YES & YES \\
NO & YES & YES \\
NO & YES & YES \\
11,738 & 11,738 & 11,738 \\
0.13 & 0.64 & 0.64 \\
\hline
\end{tabular}


Table 6: Seasonality by year (continued). Panel C repeats the exercise from Panel B, replacing bank market concentration with the dollar volume of flows to mutual funds investing in corporate bonds. Flows are estimated as the change in total net assets, less year-end returns on the prior year's total net assets and are standardized to have mean zero and unit standard deviation. Corporate bond funds are flagged as those funds with CRSP mutual find style codes ICQH (high quality corporate bonds), ICQM (medium quality corporate bonds), and ICQY (high yield corporate bonds). Other controls are the same as those reported in Panel B.

Panel C: Seasonal Effect (holdout sample) X Corporate Bond Fund Flows Loan Spread (in basis points)

(1) (2) (3)

\begin{tabular}{lcccc} 
Seasonal Effect (holdout sample) & $1.75^{1}$ & $0.57^{1}$ & -1.35 \\
& $(0.39)$ & $(0.21)$ & $(1.27)$ \\
Seasonal Effect (holdout sample) X \% Corporate Bond Fund Flows & $-1.09^{1}$ & $-0.41^{5}$ & $-0.49^{5}$ \\
& $(0.33)$ & $(0.21)$ & $(0.22)$ \\
Seasonal Effect (holdout sample) X \% Mean Spreads & & & 0.01 \\
& & & $(0.01)$ \\
Seasonal Effect (holdout sample) X \% Std. Dev Monthly Spreads & & & -0.02 \\
& & & $(0.02)$ \\
Time Dummies & YES & YES & YES \\
Deal Purpose Dummies & NO & YES & YES \\
Industry Dummies & NO & YES & YES \\
Ratings Dummies & NO & YES & YES \\
Other Controls & NO & YES & YES \\
Observations & 11,164 & 11,164 & 11,164 \\
$\mathrm{R}^{2}$ & 0.14 & 0.65 & 0.65 \\
\hline
\end{tabular}


Table 7: Seasonality and industry concentration. We estimate the seasonal adjusted $\mathrm{R}^{2}$ from a regression of mean monthly loan spreads from 47 Fama-French industries on 12 monthly time dummies. Industries with less than 120 months of data are dropped. We then regress adjusted $\mathrm{R}^{2}$ on an industry level measure of bank concentration. The measure consists of the percentage of loan volume led by the top ten banks in a given industry each year, estimated yearly and averaged from 1990-2012. Controls for the mean loan spread and the volatility of annual mean loan spreads (both in basis points) in that industry are also included, as well as the average annual logged volume of issuance in that industry. Standard errors are robust to heteroskedasticity and are reported in parentheses. Statistical significance at the 1, 5, or $10 \%$ levels is reported as superscripts.

\begin{tabular}{lcc} 
Adjusted Seasonal R $\mathrm{R}^{2}$ by industry & $(1)$ & $(2)$ \\
\hline & & \\
\% volume of loans led by the top 10 banks & $0.132^{1}$ & $0.115^{1}$ \\
& $(0.031)$ & $(0.037)$ \\
Industry size & & $-0.184^{1}$ \\
& & $(0.067)$ \\
Industry mean loan spread & -0.000 \\
& & $(0.000)$ \\
Industry volatility loan spread & 0.000 \\
& & $(0.000)$ \\
Observations & 47 & 47 \\
$\mathrm{R}^{2}$ & 0.31 & 0.37 \\
\hline
\end{tabular}


Table 8: Seasonal poaching of borrowers by outsider banks. We report probit regressions of whether a loan to an investment grade rated borrower was arranged by a bank (or banks) outside of the prior year's top 10 league table (a volume weighted ranking of lead arranger activity). The seasonal effect on loan spreads is the predicted seasonal loan spread using average monthly spreads from the holdout sample. Spreads are reported in percentages here, so the marginal effect denotes the change in probability of a non-top-ten bank leading a loan based on a 1 percentage point change in spread. Column 3 estimates a linear probability model with firm fixed effects. Standard errors clustered by firm and month are reported in parentheses. Statistical significance at the 1, 5, or $10 \%$ levels is reported as superscripts.

\begin{tabular}{|c|c|c|c|}
\hline Non top 10 bank served as lead arranger(s) & $(1)$ & $(2)$ & (3) \\
\hline Seasonal Effect on Loan Spreads (\%) & $\begin{array}{c}1.30^{5} \\
(0.54)\end{array}$ & $\begin{array}{l}0.90^{10} \\
(0.53)\end{array}$ & $\begin{array}{c}0.22^{5} \\
(0.11)\end{array}$ \\
\hline Marginal Effect & 0.30 & 0.19 & \\
\hline $\ln$ (Assets) & & $\begin{array}{l}-0.20^{1} \\
(0.03)\end{array}$ & $\begin{array}{c}-0.03^{10} \\
(0.02)\end{array}$ \\
\hline Operating Profit/Assets & & $\begin{array}{l}-1.82^{1} \\
(0.54)\end{array}$ & $\begin{array}{c}-0.08 \\
(0.14)\end{array}$ \\
\hline Total Debt/Assets & & $\begin{array}{c}-0.00 \\
(0.21)\end{array}$ & $\begin{array}{c}0.08 \\
(0.07)\end{array}$ \\
\hline PP\&E/Assets & & $\begin{array}{c}0.36^{5} \\
(0.18)\end{array}$ & $\begin{array}{c}-0.18^{10} \\
(0.10)\end{array}$ \\
\hline $\ln$ (Maturity) & & $\begin{array}{c}-0.04 \\
(0.04)\end{array}$ & $\begin{array}{c}0.00 \\
(0.01)\end{array}$ \\
\hline Secured & & $\begin{array}{c}0.29^{1} \\
(0.08)\end{array}$ & $\begin{array}{c}0.08^{1} \\
(0.02)\end{array}$ \\
\hline Time Dummies & YES & YES & YES \\
\hline Deal Purpose Dummies & NO & YES & YES \\
\hline Industry Dummies & NO & YES & YES \\
\hline Ratings Dummies & NO & YES & YES \\
\hline Firm Fixed Effects & NO & NO & YES \\
\hline Observations & 6,256 & 6,256 & 6,256 \\
\hline (Pseudo) $\mathrm{R}^{2}$ & 0.06 & 0.14 & 0.48 \\
\hline
\end{tabular}


Figure 1: Loan Spread Seasonality. The solid line in Figure 1 depicts average monthly spreads over base rate for loans negotiated between 1999 and 2007, where the month represents the loan's effective date. The dashed line represents a simple out-of-sample seasonal prediction based on the average spread for each calendar month from 1987 to 1998.

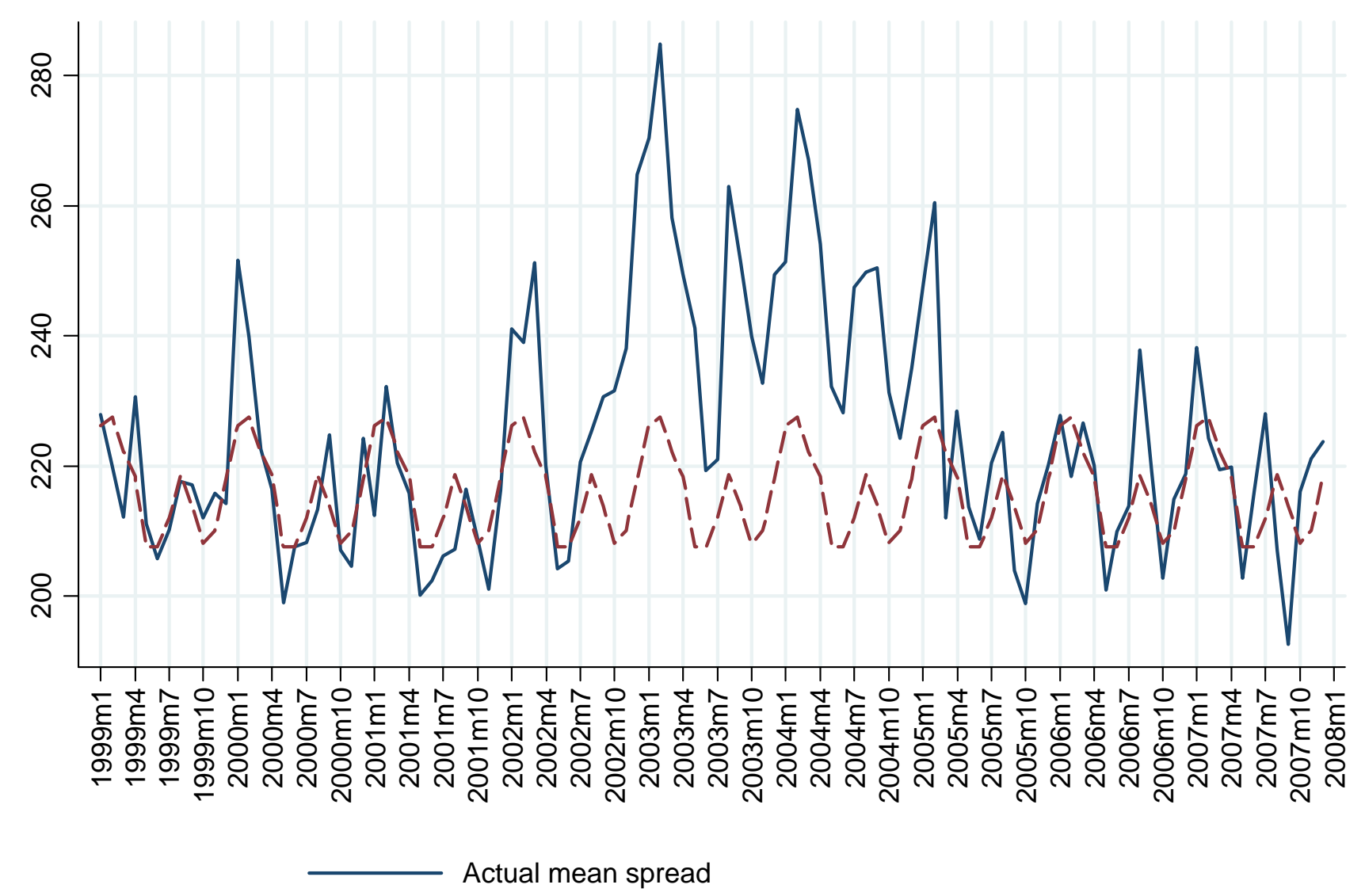

- - - - Seasonal monthly average (estimated 1987-1998) 
Figure 2: Loan Spread Seasonality. The dashed line in Figure 2 depicts average monthly spreads over base rate for loans negotiated between 1987 and 2012, where the month represents the loan's effective date.

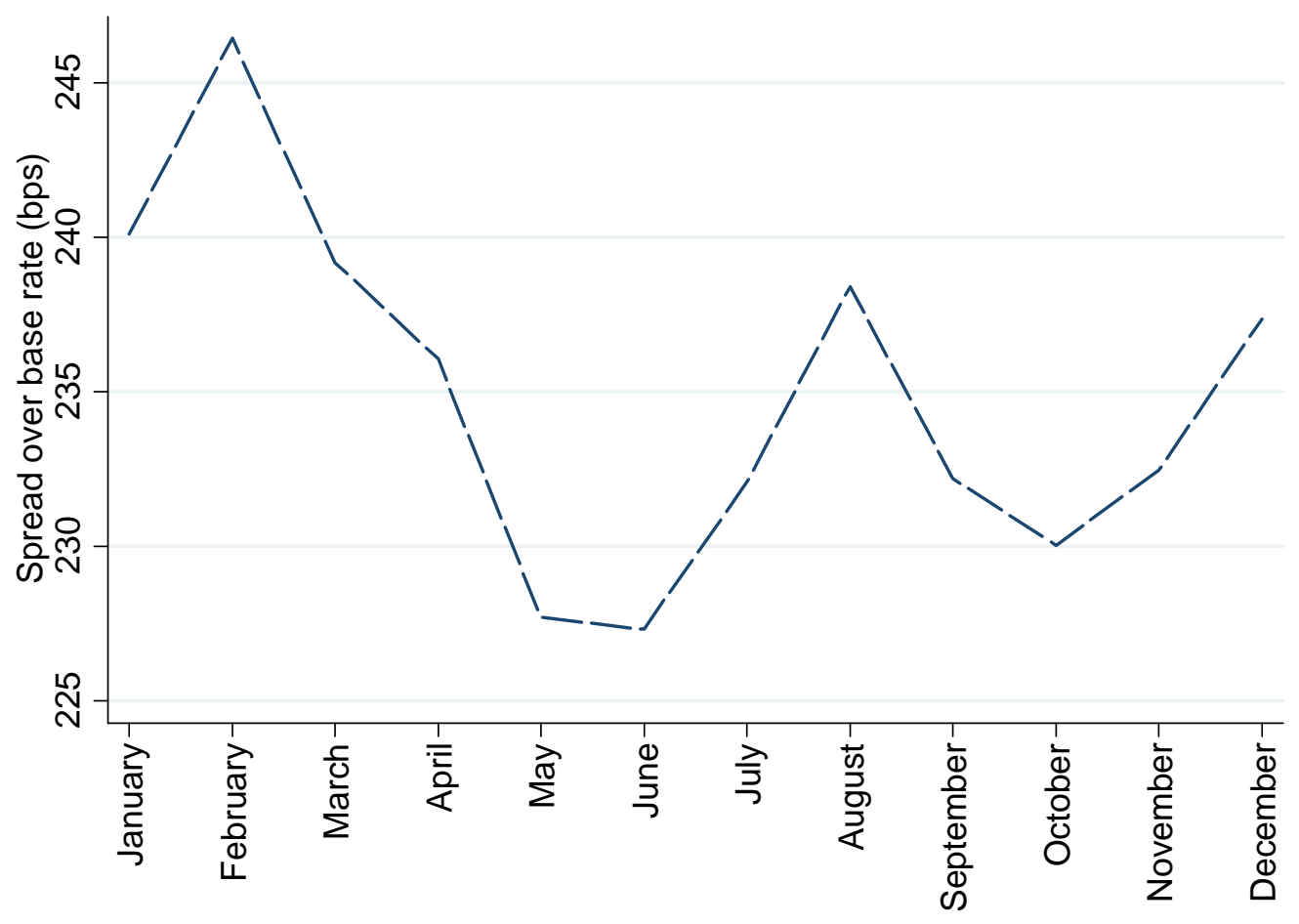


Figure 3: Seasonal spreads and loan volume. Figure 3a reports the average spreads on new issue loans and average monthly loan volumes for each calendar month for DealScan sample from 1987-2012 based on the loan effective date. Figure 3b replaces the $\mathrm{x}$-axis with the average number of loans issued per month.

Figure 3a

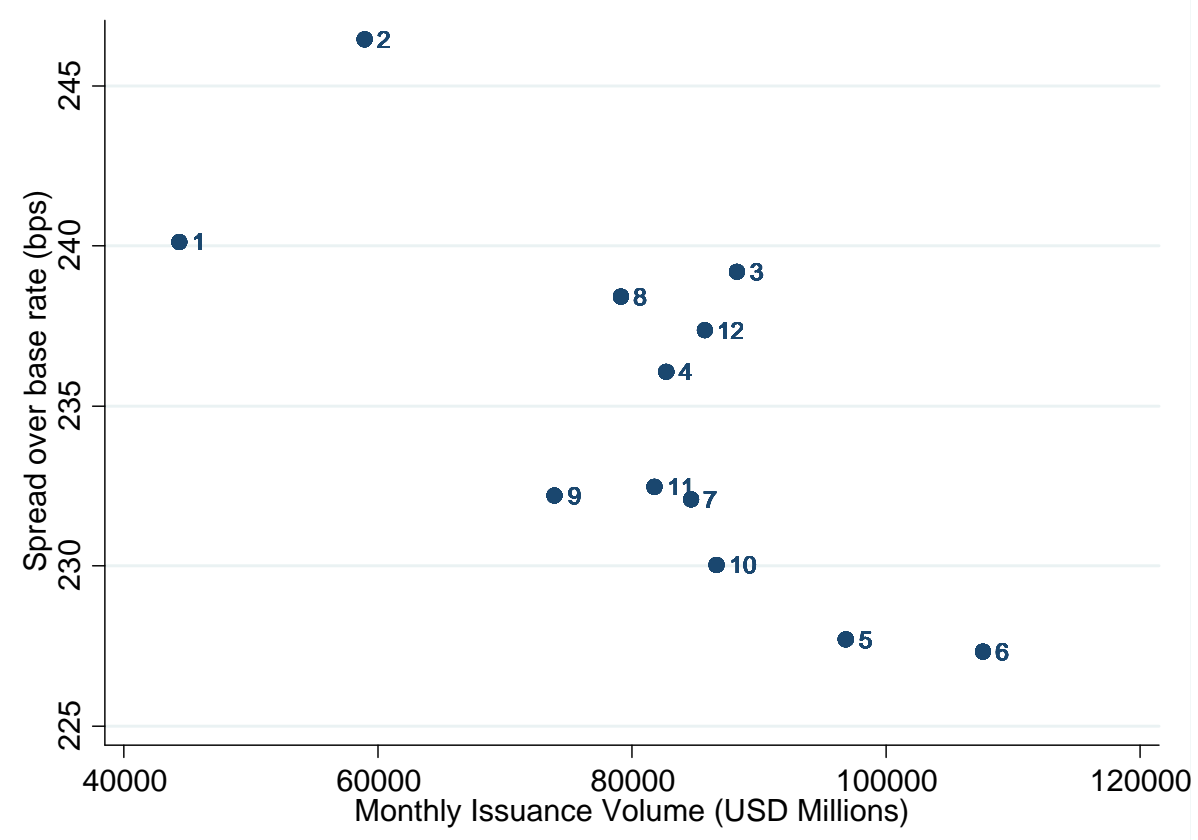

Figure 3b

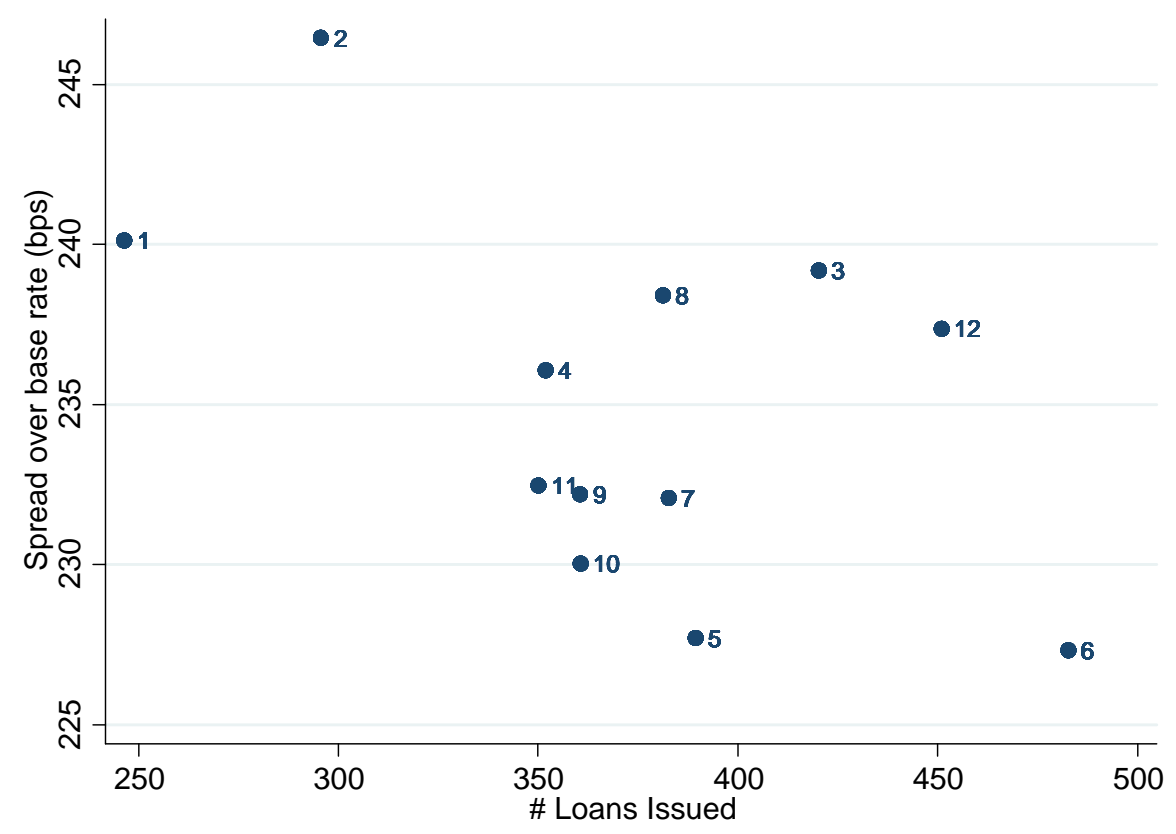


Figure 4: Seasonality by year and lender competition. We plot the sensitivity to seasonal patterns estimated in Table 6 against the percentage of loan volume arranged by the top ten lead arrangers in the prior year.

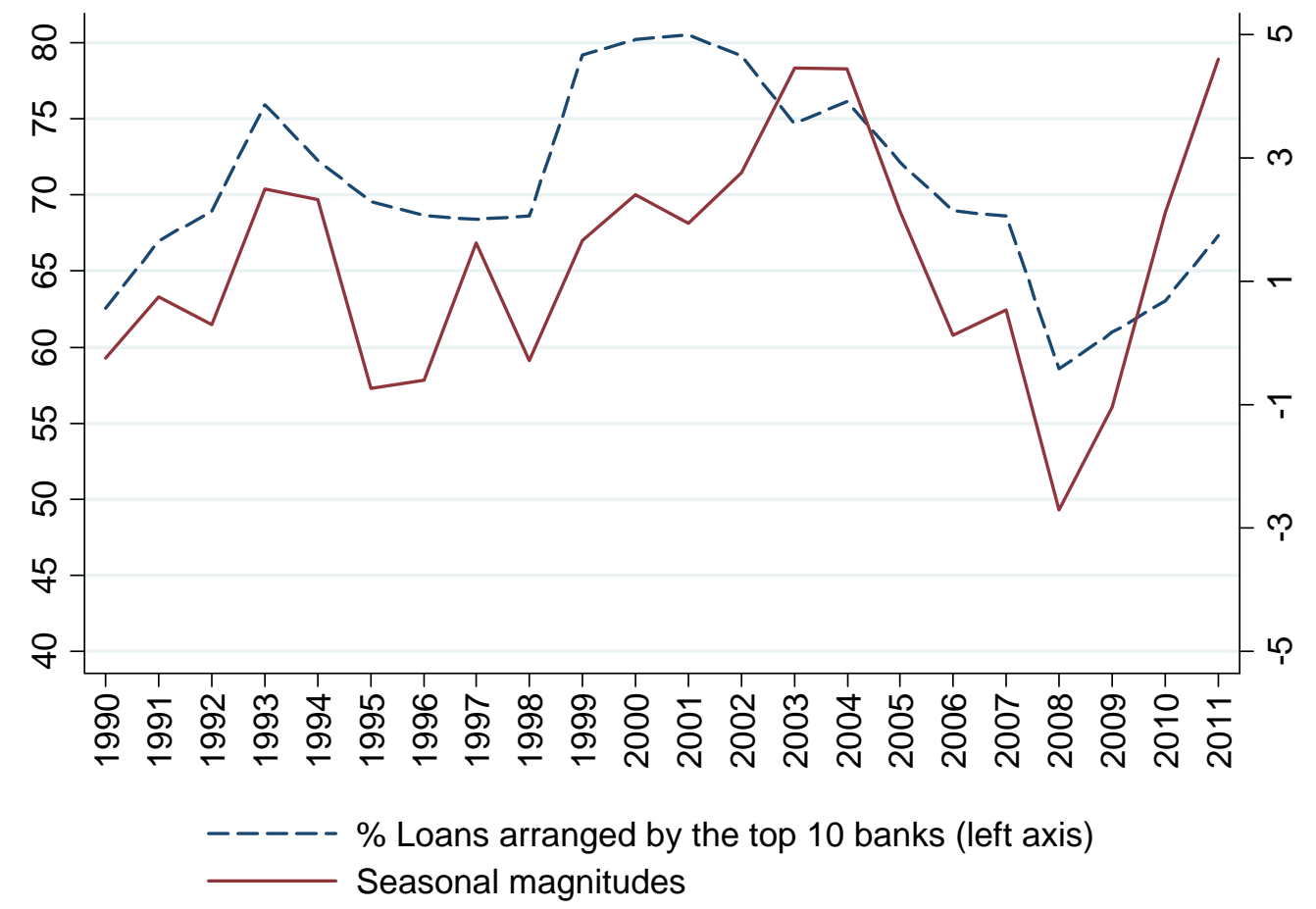


Figure 5: Seasonality by industry and lender competition. The top panel (Figure 5a) plots the adjusted $\mathrm{R}^{2}$ from a time series regression of average monthly spreads on calendar month dummies for 47 FamaFrench industries, dropping industries with less than 120 monthly observations, against the average percentage of total loan volume in that industry that is led by the top ten banks in that industry. The bottom panel (Figure $5 \mathrm{~b}$ ) plots average monthly spreads for the highest and lowest $\mathrm{R}^{2}$ industries.

Figure 5a

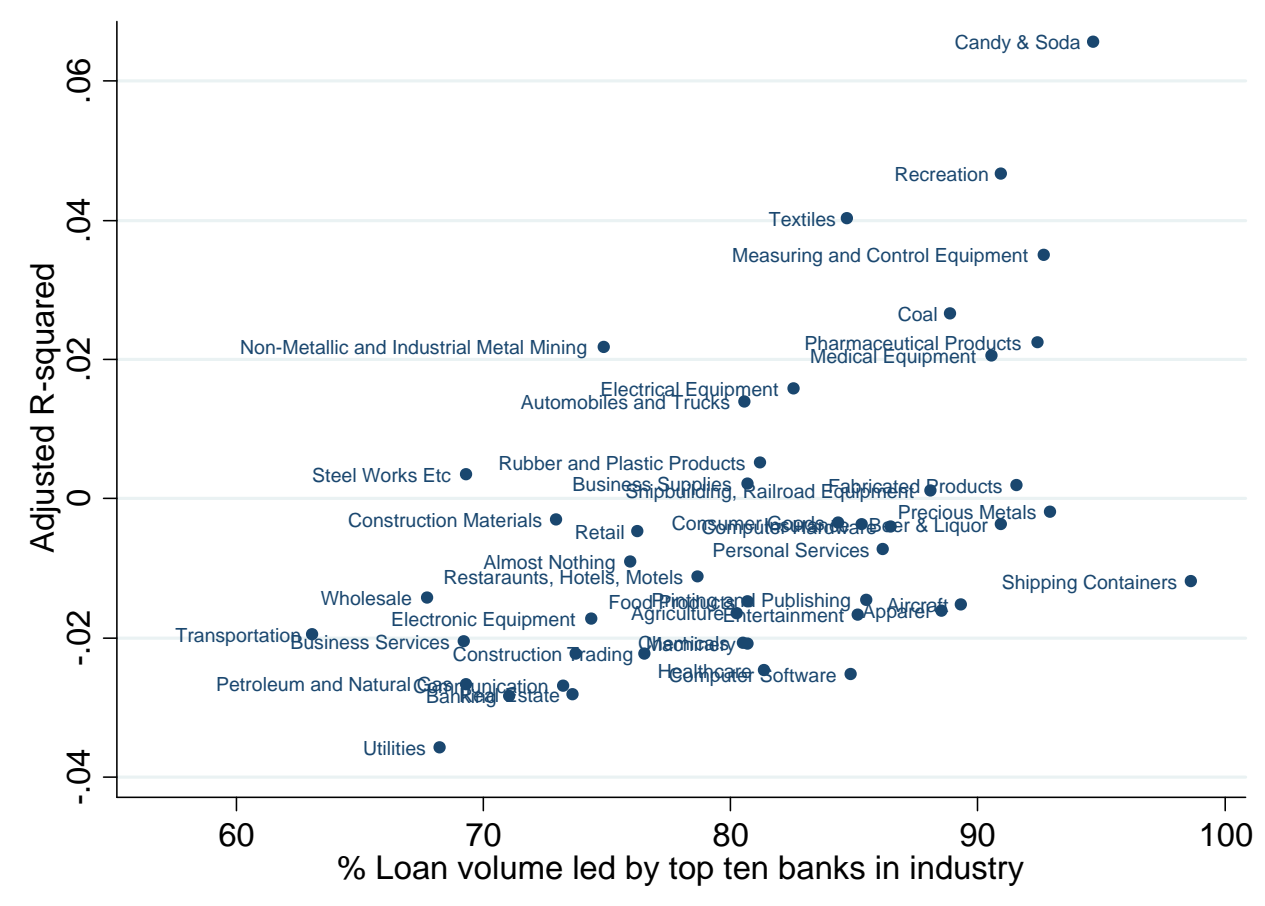


Figure 5b

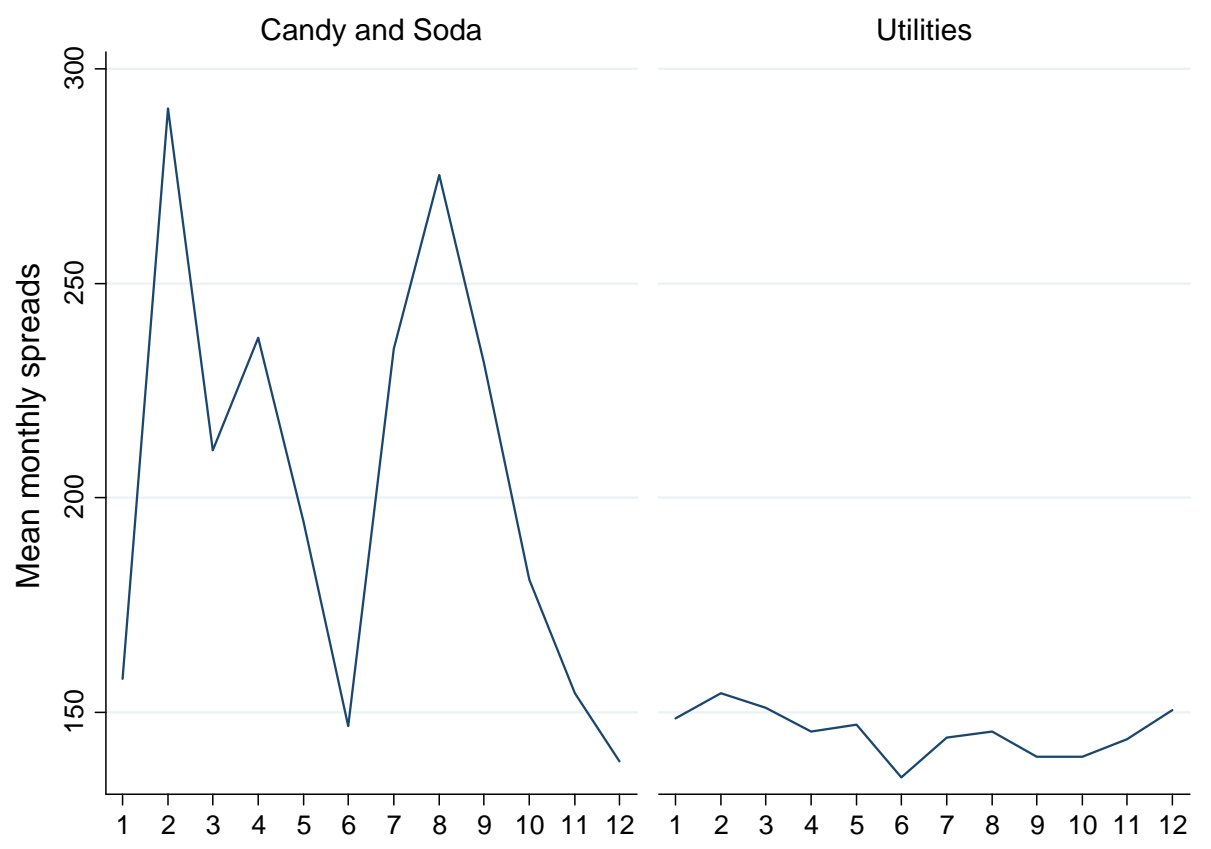


Figure 6: Seasonal market structure and loan spreads. Figure 6 plots the percentage of loans to investment grade rated borrowers which were arranged by a bank that was not ranked in the top ten of prior year's lead arranger league tables (left axis) and the average seasonal loan spread by calendar month (in basis points) (right axis).

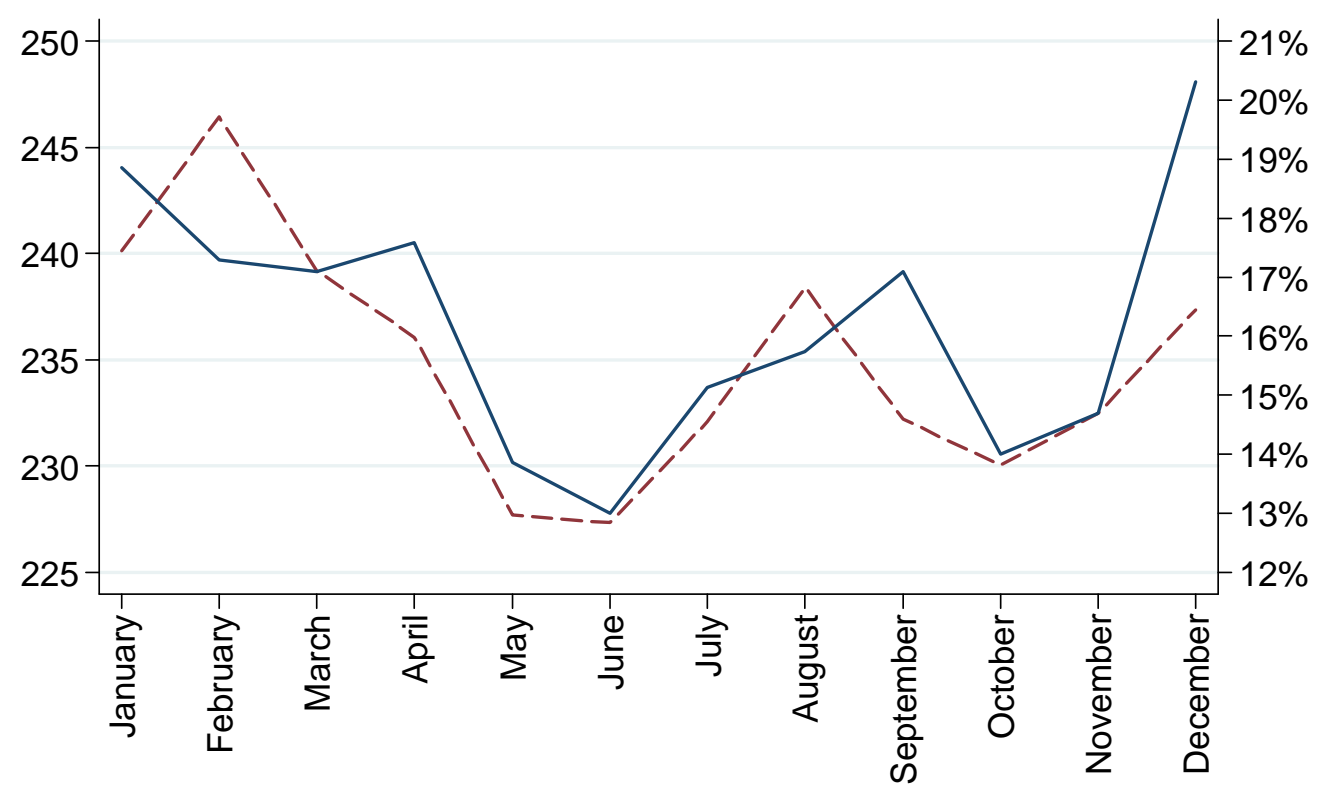

- - - - Average seasonal spread

$\%$ investment grade loans led by banks outside the top 10 


\section{Appendix A:}

Figure A1: Fee Seasonality. We note that fees follow similar seasonal patterns to all-in-drawn spreads. Below, we plot the average monthly fees of loan facilities by month. Averages are constructed first at the facility level, where we include the most common fee types: facility fees, upfront fees, commitment fees, annual fees, and standby letter of credit fees. After calculating the average fees per transaction, we take the monthly average across the 12 calendar months. The second plot captures the average undrawn fee: annual fees plus any commitment fees on transactions with a revolving loan component.
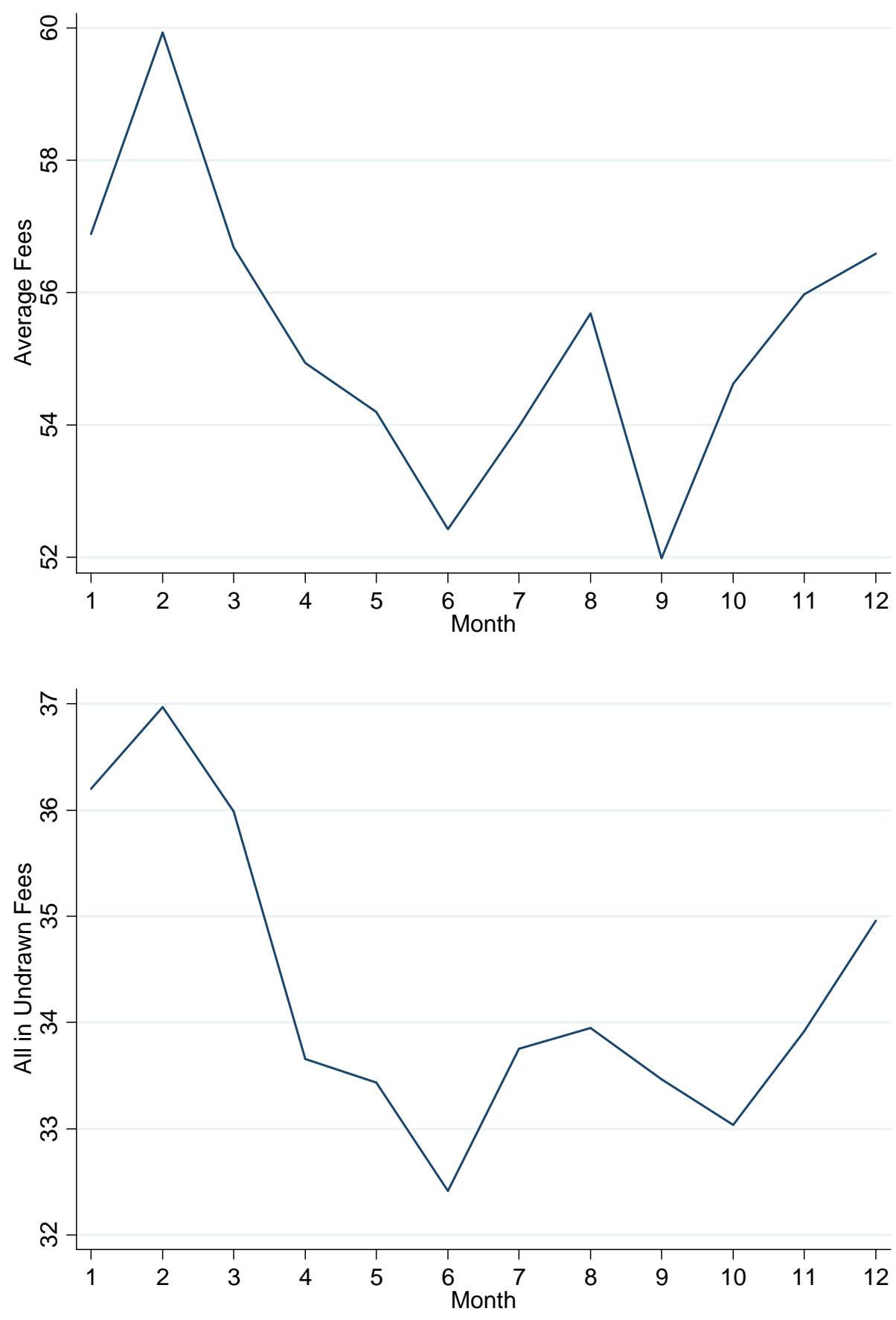
Appendix B: Robustness: Loan Level Seasonality. We re-estimate the regressions from Table 2, column (4) under a variety of subsamples and variants of seasonality for robustness. Column 1 subsamples among just packages that include revolving credit facilities (column 1 below). Column 2 restricts loans to just those with use of proceeds reported as "general corporate purposes" or "working capital". Column 3 adjusts the seasons so the expensive season better matches the global maximum average spreads seen in Figure 3 (January, February, and March) as opposed to the local peaks in pricing (January, February, and August). Column 4 excludes repeat issuers from the sample, focusing only on each borrower's first DealScan transaction to ensure that transactions reflect new deals and not just amendments or refinancings of existing transactions. Standard errors clustered by firm and month are reported in parentheses. Statistical significance at the 1, 5, or 10\% levels is reported as superscripts.

\begin{tabular}{|c|c|c|c|c|}
\hline Loan Spread (in basis points) & $(1)$ & $(2)$ & (3) & (4) \\
\hline Cheap Season & $\begin{array}{c}0.88 \\
(1.92)\end{array}$ & $\begin{array}{l}-0.16 \\
(2.47)\end{array}$ & $\begin{array}{l}-0.47 \\
(1.85)\end{array}$ & $\begin{array}{l}-7.75^{5} \\
(3.92)\end{array}$ \\
\hline Expensive Season & $\begin{array}{l}8.11^{1} \\
(2.52)\end{array}$ & $\begin{array}{l}8.70^{1} \\
(3.30)\end{array}$ & $\begin{array}{l}5.46^{5} \\
(2.75)\end{array}$ & $\begin{array}{c}3.32 \\
(4.30)\end{array}$ \\
\hline $\ln$ (Maturity) & $\begin{array}{c}-10.91^{1} \\
(2.42)\end{array}$ & $\begin{array}{l}-2.90 \\
(2.13)\end{array}$ & $\begin{array}{l}-2.80^{10} \\
(1.55)\end{array}$ & $\begin{array}{c}-13.25^{1} \\
(3.22)\end{array}$ \\
\hline Secured & $\begin{array}{l}32.53^{1} \\
(3.38)\end{array}$ & $\begin{array}{l}16.90^{1} \\
(4.50)\end{array}$ & $\begin{array}{l}23.93^{1} \\
(3.45)\end{array}$ & $\begin{array}{l}28.40^{1} \\
(5.52)\end{array}$ \\
\hline $\ln$ (Assets) & $\begin{array}{l}-0.86 \\
(2.75)\end{array}$ & $\begin{array}{c}4.88 \\
(3.53)\end{array}$ & $\begin{array}{c}1.10 \\
(2.85)\end{array}$ & $\begin{array}{l}-6.07^{1} \\
(1.71)\end{array}$ \\
\hline Operating Profit/Assets & $\begin{array}{c}-203.10^{1} \\
(22.98)\end{array}$ & $\begin{array}{c}-195.79^{1} \\
(33.76)\end{array}$ & $\begin{array}{c}-195.61^{1} \\
(23.68)\end{array}$ & $\begin{array}{r}-150.10^{1} \\
(28.04)\end{array}$ \\
\hline Total Debt/Assets & $\begin{array}{l}50.64^{1} \\
(9.82)\end{array}$ & $\begin{array}{c}62.12^{1} \\
(14.32)\end{array}$ & $\begin{array}{l}35.76^{1} \\
(9.87)\end{array}$ & $\begin{array}{l}43.61^{1} \\
(9.04)\end{array}$ \\
\hline PP\&E/Assets & $\begin{array}{c}15.26 \\
(14.11)\end{array}$ & $\begin{array}{c}4.45 \\
(21.94)\end{array}$ & $\begin{array}{c}15.17 \\
(14.16)\end{array}$ & $\begin{array}{l}-0.02 \\
(8.35)\end{array}$ \\
\hline Time Fixed Effects & YES & YES & YES & YES \\
\hline Deal Purpose Fixed Effects & YES & YES & YES & YES \\
\hline Industry Fixed Effects & - & - & - & YES \\
\hline Ratings Fixed Effects & YES & YES & YES & YES \\
\hline Firm Fixed Effects & YES & YES & YES & NO \\
\hline $\begin{array}{l}\text { Observations } \\
\mathrm{R}^{2}\end{array}$ & $\begin{array}{c}7,863 \\
0.82 \\
\end{array}$ & $\begin{array}{c}5,892 \\
0.82 \\
\end{array}$ & $\begin{array}{c}11,414 \\
0.77 \\
\end{array}$ & $\begin{array}{c}2,642 \\
0.61\end{array}$ \\
\hline Expensive-Cheap & $\begin{array}{l}7.23^{1} \\
(2.73)\end{array}$ & $\begin{array}{l}8.87^{5} \\
(3.45)\end{array}$ & $\begin{array}{l}5.93^{5} \\
(2.85)\end{array}$ & $\begin{array}{l}11.07^{5} \\
(4.65)\end{array}$ \\
\hline
\end{tabular}


Robustness to clustering alternatives. We report the results from Table 2, columns 3-8, based on different ways of clustering standard errors. The first set of regressions replicate Table 2 columns 1-8 but clustering by firm and year as opposed to firm and month. The second set of results clusters just by firm. Statistical significance at the 1,5 , or $10 \%$ levels is denoted with ${ }^{1}{ }^{5}$, or ${ }^{10}$, respectively.

\begin{tabular}{|c|c|c|c|c|c|c|}
\hline Clustering: Firm \& Year & & & & & \multicolumn{2}{|c|}{ CDS Sample } \\
\hline Loan Spread (in basis points) & (3) & (4) & (5) & (6) & $(7)$ & $(8)$ \\
\hline Seasonal Effect (holdout sample) & & & $\begin{array}{l}0.60^{5} \\
(0.27)\end{array}$ & $\begin{array}{l}0.51^{5} \\
(0.21)\end{array}$ & & $\begin{array}{l}0.73^{1} \\
(0.19)\end{array}$ \\
\hline Cheap Season (May, June, Oct) & $\begin{array}{c}-1.80 \\
(1.63)\end{array}$ & $\begin{array}{c}-0.51 \\
(1.90)\end{array}$ & & & $\begin{array}{c}-2.42 \\
(2.34)\end{array}$ & \\
\hline Expensive Season (Jan, Feb, Aug) & $\begin{array}{l}5.51^{5} \\
(2.75)\end{array}$ & $\begin{array}{l}5.31^{5} \\
(2.42)\end{array}$ & & & $\begin{array}{c}4.97 \\
(4.23)\end{array}$ & \\
\hline Expensive-Cheap & $\begin{array}{c}7.31^{1} \\
(2.78)\end{array}$ & $\begin{array}{l}5.82^{5} \\
(2.35)\end{array}$ & & & $\begin{array}{c}7.39^{5} \\
(3.16)\end{array}$ & \\
\hline $\begin{array}{l}\text { Clustering: Firm } \\
\text { Loan Spread (in basis points) }\end{array}$ & (3) & (4) & (5) & (6) & $\begin{array}{c}\text { CDS } \\
(7)\end{array}$ & $\begin{array}{l}\text { iple } \\
(8)\end{array}$ \\
\hline Seasonal Effect (holdout sample) & & & $\begin{array}{l}0.60^{1} \\
(0.18)\end{array}$ & $\begin{array}{l}0.51^{1} \\
(0.19)\end{array}$ & & $\begin{array}{l}0.73^{5} \\
(0.31)\end{array}$ \\
\hline Cheap Season (May, June, Oct) & $\begin{array}{l}-1.80 \\
(1.68)\end{array}$ & $\begin{array}{l}-0.51 \\
(1.74)\end{array}$ & & & $\begin{array}{l}-2.42 \\
(2.38)\end{array}$ & \\
\hline Expensive Season (Jan, Feb, Aug) & $\begin{array}{l}5.51^{5} \\
(2.15)\end{array}$ & $\begin{array}{l}5.31^{5} \\
(2.29)\end{array}$ & & & $\begin{array}{c}4.97 \\
(4.15)\end{array}$ & \\
\hline Expensive-Cheap & $\begin{array}{l}7.31^{1} \\
(2.25)\end{array}$ & $\begin{array}{c}5.82^{5} \\
(2.38)\end{array}$ & & & $\begin{array}{l}7.39^{10} \\
(4.15)\end{array}$ & \\
\hline
\end{tabular}




\section{Appendix C: Examples of Firms that Borrow in the Expensive Periods}

Finish Line signed a new \$60M loan agreement with lenders on February 21, 2003 to allow for increased capital expenditures. ${ }^{26}$ The Finish Line, Inc. is a mall-based specialty retailer which operates under the Finish Line and Running Specialty brand names. They are retailers of athletic shoes, apparel and accessories. Sales were up $40 \%$ for the year on a comparable store basis, while the sales forecast for the next year was raised by $31 \%$ (from $\$ 640 \mathrm{M}$ to $\$ 837 \mathrm{M}$ ). ${ }^{27}$ This growth was considerably above other athletic specialty retailers and was surprising given the "geopolitical and macroeconomic conditions in the United States, which have negatively impacted many other specialty retailers." 28 The growth in sales and the subsequent decision to expand capacity significantly was driven in part by Nike's decision to move more of its high-end shoes to Finish Line after the relationship between Nike and Foot Locker, a competitor of Finish Line, deteriorated. ${ }^{29}$ Nike reduced shipments to Foot Locker by $40 \%$ over the firms' dispute over selection and price of shoes which Nike sold to Foot Locker. ${ }^{30}$ Finish Line Inc. announced that 2004 capital expenditures was projected to be $\$ 48 \mathrm{M}$ (an 85\% increase over the prior year) to fund the build out of 50 new stores in the next year (which was greater than earlier plans) and the remodeling of 15-20 existing stores.

RWE AG closed on a 9B Euro loan on January 12, 2009. ${ }^{31}$ The purpose of the loan was to finance the takeover of Essent Network. RWE AG is a German electric utility that supplies electricity and gas principally in Europe. Essent Network is a Dutch utility company that distributed electricity and natural gas and also provides related services to both industrial and private customers. Essent announced that they were looking for a new partner in June 2008. RWE's interest in Essent was reported by the financial daily Boersen-Zeitung on November 12, 2008. ${ }^{32}$ Essent Networks provided RWE an entry into a new market and helped their carbon profile. The cost of CO2 emission certificates are a significant burden for RWE. ${ }^{33}$ On January 8 ${ }^{\text {th }}, 2009$ the Dutch newspaper Het Financieele Dagblad said RWE AG "is the most serious candidate to take over Dutch peer Essent N.V.” The firms announced they had reached an all-cash agreement on January 12, 2009. As Leonard Birnbaum, RWE's Chief Strategy Officer said, they "waited for the right opportunity to arise". ${ }^{34}$ The unpredictability of the opportunity made it difficult to plan financing for such a large transaction until a deal was certain. RWE did not want to delay the transaction either, but instead wanted to take advantage of the difficulty created for competing bidders by

\footnotetext{
${ }^{26}$ Finish Line Inc. repurchased no shares in the prior quarter even though they had repurchased shares in previous quarters. Shanley, John, and Christopher Svezia, March 31, 2014, "The Finish Line Inc.” Wells Fargo Securities, Inc.

${ }^{27}$ Finish Line Inc. Q4 2002 Financial Release Conference Call, March 28, 2003.

${ }^{28}$ Shanley, John, and Christopher Svezia, March 31, 2014, “The Finish Line Inc.” Wells Fargo Securities, Inc.

29 "Indianapolis-Based Finish Line Posts Robust Results during Fourth Quarter” Indianapolis Star, March 28, 2014.

30 “....management noted that it believes its store traffic levels have improved considerably as a direct result of increased elite launch product now found in The Finish Line and the exclusive footwear items from its largest vendor (Nike)." Shanley, John, and Christopher Svezia, March 31, 2014, "The Finish Line Inc.” Wells Fargo Securities, Inc. Inventory also rose significantly with the greater sales expectations and store openings. Finish Line Inc. Q4 2002 Financial Release Conference Call, March 28, 2003.

${ }^{31}$ RWE AG Earnings Presentation, February 26, 2009.

${ }^{32}$ Dow Jones Newswire, November 12, 2008.

${ }^{33}$ RWE AG Earnings Presentation, February 26, 2009.

${ }^{34}$ RWE AG Earnings Presentation, August 13, 2009.
} 
the financial market conditions. ${ }^{35}$ RWE announced lower earnings for the second quarter due in part to the "upfront costs of financing the Essent acquisition.,"36

W-H Energy Services signed a new \$375M loan agreement on February 6, 2006. W-H Energy Services, Inc. is an oil field services company that provides products and services for use in the drilling, completion, and production of oil and natural gas wells. Demand for the completion and production products and services depend upon the success of the first stage: drilling. It is thus volatile and unpredictable. Their business had been focused in off-shore drilling (the Gulf region), but they planned to expand into land based business (the Rockies region). Then demand for their products and services increased dramatically at the end of 2005. "Completion and Workover had an outstanding quarter and the largest variance versus our forecast". ${ }^{37}$ Revenues in this division grew $45 \%$ on an annualized basis. ${ }^{38}$ The unexpectedly high growth in this sector lead to "very, very high utilization rates". ${ }^{39}$ This led to a planned increase in capital expenditure for 2006 due to the greater customer demand, forcing the firm to restructure their existing credit which limited capital expenditure below now necessary levels. ${ }^{40}$

Eaton Corporation closed a \$3B loan on January 25, 2008. The purpose of the loan was to finance Eaton's \$2.23B acquisition of Moeller Group, the largest acquisition in Eaton's history. ${ }^{41}$ Eaton announced the acquisition of Phoenixtec Power Company for $\$ 565 \mathrm{M}$ on the same day. ${ }^{42}$ Eaton is a diversified industrial manufacturer and the Moeller Group is a leading supplier of components for commercial and residential building applications, and industrial controls for industrial equipment applications. The Moeller acquisition expanded Eaton's production and distribution assets in Eastern and Western Europe as well as reduced Eaton's dependence on the automotive and truck markets. ${ }^{43}$ With the acquisition, Eaton's assets are better balanced between early and late-cycle business and thus better able to absorb the reduction in demand for automotive and construction equipment. ${ }^{44}$

Neither Eaton nor Doughty Hanson \& Co (a private equity firm) made any public announcement about the planned merger until December 20th, 2007. Under Doughty Hanson \& Co.'s ownership, the Moeller Group had increased their core revenues by $26 \%$ in two years, but the private equity firm felt now was the right time to exit. ${ }^{45}$ Since there were no public announcements or leaks prior to Eaton announcing they had signed a deal, Eaton's management may have wanted to wrap the negotiations up

35 "We're determined to benefit from the crisis," executive board member Leonhard Birnbaum told reporters in December, Wall Street Journal online edition, January 9 ${ }^{\text {th }}, 2009$.

${ }^{36}$ RWE AG Earnings Presentation, August 13, 2009.

${ }^{37}$ Credit Suisse Equity Research Report on W-H Energy Services, January 31, 2006.

38 "First Read: W-H Energy Services, UBS Investment Research, January 30, 2006.

${ }^{39}$ Ken White (President \& CEO, W-H Energy Services) W-H Energy Services earnings conference call, April 27, 2006.

40 "WHQ introduced its 2006 capex guidance of \$150M, up 60\% from 2005... in response to strong customer demand.” Credit Suisse Equity Research Report on W-H Energy Services, January 31, 2006.

41 "Eaton makes \$2.8B buys in Asia-Europe” Associated Press, December 20" 2007.

42 The acquisitions were financed with a combination of debt, equity, and cash. "Eaton Agrees To Acquire The Moeller Group And Launches Tender Offer To Acquire Phoenixtec Power Company Ltd.” Eaton Press Release, December $20^{\text {th }}, 2007$.

43 “Eaton makes \$2.8B buys in Asia-Europe” Associated Press, December 20 ${ }^{\text {th }}, 2007$.

${ }^{44}$ Nigel Coe and Nicole DeBalse, "Electrifying the Revenue Base”, Deutsche Bank, December 21 2007.

45 "Now is the right time for Moeller to enter the next phase of growth by becoming a part of a major global industrial group with a compelling strategic and geographic fit.” Claus Felder, Managing Partner of Doughty Hanson \& Co as quoted in "Doughty Hanson Sells Moeller Group to Eaton Corporation” Doughty Hanson \& Co Press Release, December 20 ${ }^{\text {th }}, 2007$. 
quickly before other bidders appeared, especially given the price they paid as favorable by equity analysts. $^{46}$

46 "We were also pleased with the pricing of the transactions... for Moeller... and... Phoenixtec - both at the lower end of comparables, which is surprising given the highly strategic nature of the deals." Nigel Coe and Nicole DeBalse, “Electrifying the Revenue Base”, Deutsche Bank, December 21 2007. 


\section{References}

Agarwal, S., Benmelech E., Bergman, N., Seru, A., 2012. Did the community reinvestment act (CRA) lead to risky lending? Working paper. National Bureau of Economic Research, Massachusetts.

Chava, S., Roberts, M., 2008. How does financing impact investment? The role of debt covenants. Journal of Finance 63, 2085-2121.

Chodorow-Reich, G., 2014. The employment effects of credit market disruptions: firmlevel evidence from the 2008 financial crisis. The Quarterly Journal of Economics 129, 1-59.

Conlisk, J., Gerstner, E., Sobel, J., 1984. Cyclic pricing by a durable goods monopolist. The Quarterly Journal of Economics 99, 489-505.

Dana, J., Anderson, E., 2009. When is price discrimination profitable? Management Science 55, 980-989.

Fama, E., French, K., 1997. Industry costs of equity. Journal of Financial Economics 43, 153-193.

Firestone, S., Rezende, M., 2015. Are banks’ internal risk parameters consistent? Evidence from syndicated loans. Journal of Financial Services Research.

Heston, S., Sadka, R., 2008. Seasonality in the cross-section of stock returns. Journal of Financial Economics 87, 418-445.

Ivashina, V., and Scharfstein, D., 2010. Bank lending during the financial crisis of 2008. Journal of Financial Economics 97, 319-338. 
Kamstra, M., Kramer, Levi, M.D, 2015. Seasonal variation in treasury returns. Critical Finance Review 4, 45-115.

Keloharju, M., Linnainmaa, J., Nyberg, P., 2013. Common factors in stock market seasonalities. Working paper. University of Chicago.

Lewis, T., McAfee, P., 2009. Introduction to Economic Analysis, Flat World Knowledge, Washington D.C.

Lins, K.V., Servaes, H., Tufano, P., 2010. What drives corporate liquidity? An international survey of cash holdings and lines of credit. Journal of Financial Economics 98, 160-176.

Martin, J. S., Santomero, A.M., 1997. Investment opportunities and corporate demand for lines of credit. Journal of Banking \& Finance 21, 1331-1350.

Meinken, K., 1955. The Demand and Price Structure for Wheat. U.S. Dept. of Agriculture, Washington D.C.

Miron, J., 1996. The Economics of Seasonal Cycles. MIT Press, Cambridge, Massachusetts.

Nair, H., 2007. Intertemporal price discrimination with forward looking consumers: application to the US market for console video-games. Quantitative Marketing and Economics 5, 239-292.

Newey, W.K., West, K.D., 1987. A simple, positive semi-definite, heteroskedasticity and autocorrelation consistent covariance matrix. Econometrica 55, 703-708. 
Oyer, P., 1998. Fiscal year ends and nonlinear incentive contracts: the effect on business seasonality. Quarterly Journal of Economics 113, 149-185.

Petersen, M., Rajan, R., 1995. The effect of credit market competition on lending relationships. Quarterly Journal of Economics 110, 407-444.

Petersen, M., 2009. Estimating standard errors in finance panel data sets: comparing approaches. Review of Financial Studies 22, 435-480.

Salop, S., Stiglitz, J. E., 1977. Bargains and ripoffs: a model of monopolistically competitive price dispersion. Review of Economic Studies 44, 493-510.

Stokey, N. L., 1979. Intertemporal price discrimination. The Quarterly Journal of Economics 93, 355-371.

Stokey, N. L., 1981. Rational expectations and durable goods pricing. Bell Journal of Economics 12, 112-128.

Varian, H. R., 1980. A model of sales. American Economic Review 70, 651-659. 